\title{
The origin of Fe-Ti-P-rich nelsonite constrained by melting experiment and inclusions in apatite: the Damiao anorthosite complex, North China Craton
}

Meng Wang ${ }^{1,2}$, Ilya Veksler ${ }^{3,4,5}$, Zhaochong Zhang ${ }^{1 *}$, Tong Hou ${ }^{2}$

1- State Key Laboratory of Geological Process and Mineral Resources, China University of Geosciences, Beijing 100083, China

2-Institut für Mineralogie, Leibniz Universität Hannover, 30167 Hannover, Germany

3- Helmholtz Centre Potsdam GFZ German Research Centre for Geosciences, Section 4.2, Telegrafenberg, Potsdam, D-14473 Germany

4-Department of Mineralogy, Technical University Berlin, Ackerstrasse 71-76, Berlin 13555, Germany

5-Perm State University, Geological Department, Bukireva 15, 614990 Perm, Russia

\footnotetext{
* Corresponding author. E-mail address: zczhang@cugb.edu.cn
} 


\begin{abstract}
Models for the nelsonite formation are currently highly contentious, with liquid immiscibility and fractional crystallisation as frequently proposed formation mechanisms. The nelsonites in the Damiao massif anorthosite complex in the North China Craton are revisited here together with experimental evidence for the existence of silica-free $\mathrm{CaO}-\mathrm{FeO}-\mathrm{Fe}_{2} \mathrm{O}_{3}-\mathrm{TiO}_{2}-\mathrm{P}_{2} \mathrm{O}_{5}$ immiscible nelsonitic liquids. Our results of differential scanning calorimetry (DSC) and internally heated pressure vessel (IHPV) demonstrate that nelsonite with the composition of one-third apatite and two-thirds Fe-Ti oxides by weight 1) completely melts well above $1450{ }^{\circ} \mathrm{C}$ at dry condition, which is in good agreement with numerous experimental studies of the $\mathrm{CaO}-\mathrm{P}_{2} \mathrm{O}_{5}-\mathrm{Fe}_{\mathrm{x}} \mathrm{O}$ system for metallurgical purposes; 2) does not melt at the temperature up to $1200{ }^{\circ} \mathrm{C}$ with presence of considerable amount of volatiles, e.g., fluorine and water. Therefore, the composition of the nelsonite cannot be molten at temperatures relevant for crystallisation of the Damiao magma. A review of experimental studies of liquid immiscibility and analyses of natural immiscible glasses show that all the liquids on the Fe- and P-rich side of the miscibility gap have at least $20 \mathrm{wt} . \%$ of aluminosilicate components.

In addition, our new analyses of apatite-hosted melt inclusions in Damiao nelsonite provide a crucial clue for the nelsonite formation. The inclusions range from $\sim 3$ to $200 \mu \mathrm{m}$ in diameter. They are ubiquitous and meet all the morphological criteria of primary melt inclusions crystallised into assemblages of daughter minerals. Almost all assemblages contain vermiculite and/or chlorite, and some contain biotite, amphibole, phlogopite and Fe-Ti oxide. Bulk compositions of analysed inclusions show large variations in $\mathrm{SiO}_{2}\left(20.79-50.16\right.$ wt. \%) and $\mathrm{FeO}_{\mathrm{t}}(13.44-32.78$ wt. \%). With a few exceptions, the inclusions are very low in $\mathrm{CaO}\left(0.04-1.51\right.$ wt. \%) and high in $\mathrm{Al}_{2} \mathrm{O}_{3}$ (10-21.17 wt. \%). The re-homogenized inclusions at $1200^{\circ} \mathrm{C}$ obtained by IHPV show similar compositional characteristics but incorporated excessive melting of the host apatite. Nevertheless, the compositions significantly differ from those of the typical immiscible Fe-rich melts despite the high Fe content and low silica. It appears that the cumulus apatite crystallised from Fe-rich, hydrated late-stage immiscible Fe-rich melt formed by liquid immiscibility occurred in the relatively early stage, i.e. prior to the arrival of aqueous fluid phase. We propose that the inclusions at Damiao record a trend of intercumulus melt evolution, which have been through liquid-liquid immiscibility but most likely have been strongly affected by separation of a hydrothermal fluid phase and the losses of alkali and Ca silicate components from the melt into the fluid.
\end{abstract}

Keywords: Nelsonite; Melt inclusion; Experimental constraints; Phase equilibria; Damiao Complex 
Fe-Ti oxides and apatite-rich rocks, called nelsonites, are most commonly associated with mafic layered intrusions and massif-type anorthosites (e.g., Kolker, 1982; Charlier et al., 2015). Models for the formation of nelsonite are highly contentious, with liquid immiscibility and fractional crystallisation being frequently opposed. In the crystal fractionation model, nelsonites have been considered to represent apatite-magnetite cumulates (e.g., Emslie, 1978; Goldberg, 1984; McLelland et al., 1994; Eales and Cawthorn, 1996; Dymek and Owens, 2001; Tegner et al., 2006; Charlier et al., 2008).

Formation by liquid-liquid separation has been proposed on the basis of experimental data and geological observations (e.g., Philpotts, 1967, 1981; Naslund, 1983; Kolker, 1982; Reynolds, 1985; Darling and Florence, 1995; Ripley et al., 1998). Unmixing of basaltic, andesitic and dacitic melts is believed to split into a rhyolitic liquid and a mafic liquid with cooling. The latter is strongly enriched in $\mathrm{Fe}, \mathrm{Ca}$ and $\mathrm{P}$, as demonstrated in laboratory experiments and confirmed by immiscibility textures in natural lavas (Roedder, 1979; Philpotts, 1982; Charlier and Grove, 2012; Kamenetsky et al., 2013; Charlier et al., 2013; Hou and Veksler, 2015). Kolker (1982) favored this model to explain field evidence such as discordant veins and dykes intruding the host anorthosite.

Referring to the study by Philpotts (1967), some authors postulate the existence of immiscible nelsonitic liquids with very low concentrations of silicate components. Almost silica-free parental liquid composed by two thirds of Fe-Ti oxides and one third of the apatite component has been recently proposed by Chen et al. (2013) for 
the large economical nelsonite deposit in the Damiao massif anorthosite complex in North China Craton. The composition differs strongly from the above-mentioned Fe-rich immiscible silicate melts coexisting with conjugate rhyolitic melts. Experimental demonstration of almost pure apatite-magnetite nelsonitic liquids has not been reproduced except the study of Philpotts (1967), in which the immiscibility of an Fe-Ti-P-rich melt were obtained at the extremely high temperature of $1420^{\circ} \mathrm{C}$. Lindsley (2003) explains that he has never been able to generate Fe-Ti oxide liquids experimentally. He concluded from experimental evidence that oxide bodies crystallize from Fe-Ti-P-rich silicate melts and are emplaced either as a crystal mush or in the solid state.

Actually fractional crystallization and liquid immiscibility are not mutually exclusive. If immiscibility occur and produce and Fe-rich silicate melt, this magma will crystallize abundant Fe-Ti oxides and apatite so that the nelsonite is actually a cumulate from the Fe-rich melt (Namur et al., 2012; Duchesne and Liegeois, 2015). Indeed, the relative proportion of oxides and apatite, ca. 2/3 oxides and 1/3 apatite (Kolker, 1982), does not necessarily indicate an origin related to immiscibility but could simply reflect cotectic proportions of Fe-Ti oxides and apatite crystallizing from a silicate melt, not sorted during the accumulation process.

In this study, we propose two complementary approaches to further constrain the origin of nelsonite associated with massif-type anorthosites, with a focus on Damiao nelsonites. The first we test using melting experiments on the proposed 'nelsonitic liquid' whether such a composition is able to crystallize Fe-Ti oxides and apatite at 
reasonable conditions. Second we investigate the composition of apatite-hosted melt inclusions to constrain independently the nature of liquids in equilibrium with nelsonites. In spite of the furtive nature of the silicate liquid immiscibility, our observations imply that the cumulus apatite and thus nelsonite probably had crystallized from an immiscible Fe-rich, silicate melt, of which compositions similar to typical immiscible Fe- and silica-rich melts previously found as apatite-hosted inclusions in Skaergaard (Jakobsen et al., 2005) and Sept Iles (Namur et al., 2010; Charlier et al., 2011) intrusions. Given that the inclusions are composed of hydrous minerals, in this contribution, we also propose that the inclusions at Damiao record a trend of Fe-enrichment of the intercumulus melt in a very late stage of the magma evolution when nelsonite precipitated, which was strongly affected by an external aqueous fluid phase and the losses of more water-soluble alkali and $\mathrm{Ca}$ silicate components from the melt into the fluid. This process probably elevated remarkably the $\mathrm{Fe}$ and $\mathrm{P}$ content in the intercumulus melts and thus enhances the mineralization. Similar mechanism could be broadly applicable to formation of massive Fe-Ti oxide ores in water-saturated magmatic systems analogous to the Damiao complex.

\section{Geological Background}

\subsection{The Damiao complex}

The Damiao complex is located at the northern margin of the North China Craton (NCC; Zhao et al., 2009). The NCC (Liu et al., 1992) is bound by the Central Asian Orogenic Belt to the north and the Qinling-Dabie and Sulu Orogens to the south (Fig. 
1a; Zhao et al., 2001). The basement rocks consist of Paleoarchean to Paleoproterozoic crystalline basement rocks that are mainly composed of mafic granulites and amphibolites and tonalite- trondhjemite-granodiorite (TTG) gneisses, and are overlain by the Proterozoic Xiong'er Group and $3.5 \mathrm{~km}$ thick Changcheng Group (Pang et al., 2008; Zhao et al., 2001; Li et al., 1995), which are mainly composed of intermediate volcanic lava and quartz sandstones, respectively.

The 1.74 Ga Damiao complex (Liu et al., 2007) is spatially associated with alkaline granitoids and rapakivi granites (Yu et al., 1993; Yang et al., 2005), thus forming a part of a typical anorthosite-mangerite-charnockite-granite (AMCG) suite (e.g., Zhang et al., 2007). It intruded into the basement rocks of NCC, known as the Dantazi and Hongqiyingzi complexes (Liu et al., 2007). The 2.49 Ga Dantazi Complex comprises dioritic-trondhjemitic-granodoritic-monzogranitic gneisses metamorphosed in amphibolite to granulite facies, and the 2.44-2.41 Ga Hongqiyingzi Complex is dominated by metamorphic mafic-granodioritic-monzogranitic gneisses. The Damiao complex is uncomformably overlain by Jurassic strata to the northeast and bounded by the high-angle east-west-trending fault (the Damiao Fault) to the south (Fig. 1a; Zhao et al., 2009).

General geological characteristics of the Damiao complex have been described by several detailed studies (e.g., Yan and Mu, 1993; Xie, 2005; Zhao et al., 2009; Chen et al., 2013). Only a short summary of basic information is presented here. The Damiao complex with an outcrop area of $\sim 120 \mathrm{~km}^{2}$ is dominated by anorthosite (85\%), leuconorite and melanorite (11\%), mangerite $(4 \%)$ and minor troctolite 
$(<1 \%)$, accompanied by ferrodioritic, gabbroic, felsic dikes and abundant Fe-Ti-(P) ores (Fig. 2; Ye et al., 1996; Chen et al., 2013). Anorthosite is transitional or locally intruded by the leuconorite and melanorite, and exhibit irregular shapes within anorthosite and leuconorite (Cao, 1988). Small volumes of mangerite bodies locally intrude into anorthosite in the northwestern part of the Damiao complex. Abundant Fe-Ti-(P) ores are distributed irregularly with various shapes and sizes.

Anorthosite and leuconorite, showing gradual contact, are mainly composed of plagioclase (60-95\%) and minor interstitial orthopyroxene (5-30\%), Fe-Ti oxide and apatite. Melanorites contain more Fe-Ti oxide and apatite than leuconorite. Mangerite is composed of plagioclase with variable amounts of perthite, K-feldspar and quartz, and minor clinopyroxene, Fe-Ti oxide, apatite and hornblende.

\subsection{Nelsonite}

Damiao Fe-Ti-P ore deposit is spatially and temporally associated with the Damiao anorthosite complex. The mine has reserves amounting to 33.3 million tonnes. The deposit is divided into three ore districts: Damiao, Heishan and Maying (Fig. 1). It has been mined for several decades at an annual production of 2 million tons of the ore with an average grade of about 36 wt. $\% \mathrm{Fe}_{2} \mathrm{O}_{3}, 7.0$ wt. $\% \mathrm{TiO}_{2}, 0.3$ wt. $\% \mathrm{~V}_{2} \mathrm{O}_{5}$ and 2.0 wt. $\% \mathrm{P}_{2} \mathrm{O}_{5}$ (Ye et al., 1996; Sun et al., 2009). Most ore bodies vary with the thickness of 10-30 $\mathrm{m}$ and extend hundred meters. Ores from different districts, ranging from nelsonite to monomineralic Fe-Ti oxide ores, contain variable modes of magnetite, ilmenite and apatite. The modal abundance of apatite in the lenses, veins or 
pods of nelsonites is high, well over $10 \%$ and up to $60 \%$ (Cao, 1988; Ye et al., 1996; Sun et al., 2009).

Occurrences of nelsonites are common in all the three ore districts. Most of the contacts between nelsonites and the wall rocks are sharp and discordant (Chen et al., 2009). Nelsonites occur as irregularly shaped bodies, including pods, dykes, veins and stockwork in the enclosing rocks. Almost all nelsonites in both Damiao and Heishan were affected by post-magmatic metamorphism or hydrothermal alteration. Thus, here we focus only on the Maying district where nelsonites are widespread and reasonably fresh.

In the Maying district, nelsonites are hosted in anorthosites and norites and show mostly discordant sharp contacts with the hosting rocks (Fig. 1b). Some of the Fe-Ti-P rich melanorites are composed of variable amounts of large plagioclase crystal (Fig. 2b). As mentioned above, the nelsonites are mainly composed of Fe-Ti oxide and apatite with highly variable proportions. The euhedral and subhedral apatite constitutes from 15 to 50 modal $\%$ in the nelsonite (Fig. 2c).

\section{Samples and methods}

\subsection{Preparation of synthetic nelsonite}

A synthetic nelsonite composition for experimental studies using differential scanning calorimetry (DSC) and internally heated pressure vessel (IHPV) experiments (see below) was prepared by sintering a mixture of reagent-grade chemicals $\left[\mathrm{SiO}_{2}\right.$, $\mathrm{Al}_{2} \mathrm{O}_{3}, \mathrm{MgO}, \mathrm{TiO}_{2}, \mathrm{CaCO}_{3}, \mathrm{Na}_{2} \mathrm{CO}_{3}, \mathrm{~K}_{2} \mathrm{CO}_{3}$ and $\left.\mathrm{Ca}_{3}\left(\mathrm{PO}_{4}\right)_{2}\right]$. The composition of the 
mixture is analogous stoichiometrically to the calculated model composition M-1 proposed by Chen et al. (2013) (Table 1). Carefully weighed amounts of the chemicals were mixed in agate mortar under acetone and sintered in a Pt crucible in laboratory electric box furnace at $1450{ }^{\circ} \mathrm{C}$ for an hour. After sintering, the reacted mixture in the crucible was quenched in the cold water.

\subsection{Differential scanning calorimetry}

Differential scanning calorimetry (DSC) experiments were carried out using a NETZSCH ${ }^{\circledR}$ DSC-404C at the Ludwig Maximilians University (LMU) in Munich, Germany. DSC measurements were carried out using a Setaram Sensys evo differential scanning calorimeter. Sample chip of about $80 \mathrm{mg}$ was placed in a $\mathrm{Pt}$ crucible and heated to $1500{ }^{\circ} \mathrm{C}$ at a heating rate of $10^{\circ} \mathrm{C} / \mathrm{min}$ in air and in Ar. Peaks in heat capacity were used to determine phase transitions.

\subsection{Melting experiment by internally heated pressure vessel (IHPV)}

In order to investigate the effect of volatiles (water and fluorine) on melting properties large amounts of dry 'nelsonitic' powder were placed into $\mathrm{Au}_{80} \mathrm{Pd}_{20}$ capsules [internal diameter $0.26 \mathrm{~cm}$; outer diameter $0.3 \mathrm{~cm}$ at $1.5 \mathrm{~cm}$ length] and stuffed with the help of a steel piston. To avoid the problem of Fe loss from the experimental charge into the capsule material (Gaetani and Grove, 1998), the $\mathrm{Au}_{80} \mathrm{Pd}_{20}$ tubes were first pre-saturated with $\mathrm{Fe}$, following the procedure from van der Laan \& Koster van Groos (1991). The inner surface of the $\mathrm{Au}_{80} \mathrm{Pd}_{20}$ tubes was coated 
with Fe using an electroplating bath. The Fe-coated $\mathrm{Au}_{80} \mathrm{Pd}_{20}$ capsules were further annealed for 24-42 $\mathrm{h}$ under a reducing $\mathrm{Ar}-\mathrm{H}_{2}$ atmosphere at $950^{\circ} \mathrm{C}$ and $1 \mathrm{~atm}$ pressure. The amount of $\mathrm{Fe}$ in the capsule alloy was determined by the mass gain; it varied between 0.3 and 0.4 wt $\%$ metallic Fe. Fluorine was added as $\mathrm{CaF}_{2}$ powder and well mixed with the nelsonitic powder before placed into the capsules. Distilled water was added to the charge using a microsyringe in five steps to achieve homogeneous $\mathrm{H}_{2} \mathrm{O}$ distribution within the capsule. These starting compositions $\mathbf{M - 2}\left(6\right.$ wt. $\left.\% \mathrm{H}_{2} \mathrm{O}\right)$ and M-3 (8 wt. $\% \mathrm{H}_{2} \mathrm{O}$ and 8 wt. $\%$ F) are listed in Table 1. Samples with addition of water were placed in liquid nitrogen for freezing before they were welded shut. This method minimizes the loss of water due to vaporization during welding. Capsules were checked for leaking by placing them into a dry furnace at $150^{\circ} \mathrm{C}$ for $1-2 \mathrm{~h}$ before they were weighed again. Sealed capsules were heated in IHPV (Berndt et al., 2002) at the intrinsic $f \mathrm{O}_{2}(\mathrm{QFM}+3.3$ buffer conditions under water-saturated condition). The IHPV was pressurized with Ar to a final pressure of $300 \mathrm{MPa}$ and then heated isobarically from $25^{\circ} \mathrm{C}$ to $1180^{\circ} \mathrm{C}(\mathbf{M}-2)$ and $1200^{\circ} \mathrm{C}(\mathbf{M}-3)$ in 2 hours, respectively. When final temperature was reached, it was held constant for $24 \mathrm{~h}$ before we rapidly quenched the samples on a copper plate. The cooling rate was $\sim 150^{\circ} \mathrm{C} / \mathrm{s}$. Temperature was controlled using two S-type thermocouples (stable within $\pm 2{ }^{\circ} \mathrm{C}$ ) and two additional S-type thermocouples were used to monitor the sample temperature. Temperature gradient across the sample is generally less than $5^{\circ} \mathrm{C}$. Re-weighing of the capsules after the experimental runs showed identical weights for most capsules indicating that no volatiles were lost during the experiments. Small chips of experimental products 
(about $2 \mathrm{~mm}$ in diameter) of each sample were prepared as polished thin sections or mounted in epoxy for electron microprobe analyses.

\subsection{Re-homogenization of melt inclusions}

More than 20 nelsonite samples were collected from an open pit of the Maying district (Fig. 1b). After optical examination under microscope, only the freshest samples were chosen for the melt inclusions study. Polished petrographic thick $(0.1$ mm) sections have been used for the study. Among the nelsonite samples, only non-fractured apatite crystals with multiphase inclusions were selected for re-homogenization using IHPV. Apatite crystals were loaded in open Pt-capsules together with graphite to reach reducing conditions. The IHPV was pressurized with Ar to a final pressure of $200 / 100 \mathrm{MPa}$ and then heated isobarically from $25^{\circ} \mathrm{C}$ to $1150^{\circ} \mathrm{C}$ or $1200^{\circ} \mathrm{C}$ in 6 hours, respectively before quenching.

\subsection{Electron microprobe analyses and elemental maps}

Daughter mineral phases of the inclusions hosted in apatite in the sections were analysed using JEOL 8230 electron probe micro-analyzer (EPMA) at the German Research Centre for Geosciences, GFZ in Potsdam, Germany. All the analyses were performed using the standard setting at $15 \mathrm{kV}$ and $15 \mathrm{nA}$ and were calibrated by references to oxide and mineral standards using the PAP correction routine. The beam size was 2-5 $\mu \mathrm{m}$ to analyse small phases. Compositional mapping of some representative inclusions in apatite was conducted using a highly sensitive 
four-segment backscattered electron (BSE) detector. We use the electron microprobe combined with X-ray, backscattered electron and cathodoluminescence (CL) maps. By scanning over a specified target inclusion, CL wavelength and X-ray element distribution maps of grains are acquired in parallel enabling direct comparison between elemental concentrations and textural features.

For the re-heated inclusions, we polished the single crystal mounts of apatite to expose inclusions to surface for EPMA analysis. These reheated melt inclusions and experimental products conducted by IHPV were measured by a "Cameca SX100" EPMA at the Institute of Mineralogy in Hannover, Germany with wavelength dispersive X-ray equipped with 5 spectrometers, reported with the software "Peak Sight" and "PAP" matrix correction (Pouchou and Pichoir 1991), which was used for element, analyzes with an acceleration voltage of $15 \mathrm{kV}$. Minerals were analyzed with a beam current of $15 \mathrm{nA}$ and a focused beam $(1 \mu \mathrm{m})$. The counting time for each element was $10 \mathrm{~s}$. Glasses were analyzed with a beam current of $8 \mathrm{nA}$ and $1 \mu \mathrm{m}-10 \mu \mathrm{m}$. The counting time for glass analyses varied between 4 and $30 \mathrm{~s}$. The following standards were used: wollastonite for $\mathrm{Si}$ and $\mathrm{Ca}, \mathrm{Al}_{2} \mathrm{O}_{3}$ for $\mathrm{Al}, \mathrm{Fe}_{2} \mathrm{O}_{3}$ for $\mathrm{Fe}, \mathrm{MgO}$ for $\mathrm{Mg}$, rutile for $\mathrm{Ti}$, albite for $\mathrm{Na}$, orthoclase for $\mathrm{K}, \mathrm{Mn}_{3} \mathrm{O}_{4}$ for $\mathrm{Mn}$, apatite for $\mathrm{P}_{2} \mathrm{O}_{5}$.

\subsection{Rock samples, whole rock analyses}

Major element concentrations in the whole-rock Damiao samples were determined using X-ray fluorescence (XRF) spectrometer at the National Research Center for Geoanalysis in Beijing. The analytical uncertainties are less than $1 \%$, 
estimated from repeated analyses of two standards (andesite GSR-2 and basalt GSR-3). Trace elements were determined by solution ICP-MS performed at the National Research Center for Geoanalysis, Beijing. Detailed explanation of the sample preparation procedures, instrument operating conditions and calibration procedures were provided by Qi and Grégoire (2000). Two standards (granite GSR-1, basalt GSR-3) were used to monitor the analytical quality.

\section{Results}

\subsection{Melting temperature of the synthetic nelsonite}

We used the differential scanning calorimetry (DSC) for determining the melting temperature of the silica-poor composition of the anhydrous nelsonite composition as proposed by Chen et al. (2013). Experiments were done in air and in Ar and the results show almost no difference. Fig. 3a illustrates that the DSC curve is relatively flat implying no phase transitions below $1300{ }^{\circ} \mathrm{C}$. Significant endothermic effects indicating the onset of extensive partial melting were observed above $1330{ }^{\circ} \mathrm{C}$. It appears that complete melting however has not been reached up to $1450{ }^{\circ} \mathrm{C}$, which is close to the upper temperature limit of the instrument.

With presence of volatiles including water $\left(6-8\right.$ wt. $\left.\% \mathrm{H}_{2} \mathrm{O}\right)$ and fluorine $(8 \mathrm{wt} . \%$ F), the nelsonitic composition is still quite refractory at the temperature both at $1180^{\circ} \mathrm{C}$ and $1200^{\circ} \mathrm{C}$ as no melt had been observed in the run products in which apatite, magnetite and perovskite are three mineral phases (Table 2). The euhedral apatite and magnetite crystals co-exist with skeletal (Fig. 3b) and spongious (Fig. 3c) perovskite. 
In summary, these observations clearly show that at a realistic geological environment (up to $1200^{\circ} \mathrm{C}$ ), the nelsonitic composition does not melt, either dry or with volatiles.

\subsection{Melt inclusions}

\subsubsection{Morphology and petrography of the melt inclusions}

Diverse populations of inclusions are found in the cumulus apatite of the nelsonite (Figs. 2c, e and f). Abundant inclusions are randomly distributed in cores and rims of host apatite. The inclusions have sizes ranging from 3 to $200 \mu \mathrm{m}$ in diameter. Most inclusions are oval or sub-rounded, especially the large ones (Fig. 4). Many of them are crystallographically oriented along the longer C-axis of apatite crystals and some have a shape of a negative apatite crystal. The inclusions are filled with multiphase mineral assemblages, fine-grained aggregates of minerals predominantly brownish or greenish in transmitted light. Almost all the inclusions, which were examined optically or analysed by the microprobe contain vermiculite and/or chlorite, and some contain biotite, amphibole, phlogopite and Fe-Ti oxides (Fig. 4).

\subsubsection{Composition of the inclusions}

We have estimated the melt composition from partly or fully crystallized melt inclusions in two ways: first by calculation of bulk inclusion compositions from modal fractions and compositions of daughter minerals and second by reheating and homogenization of daughter mineral assemblages to glasses (Jakobsen et al., 2011). 
a) Modal abundance estimation

Modal abundances of daughter minerals for individual inclusions were estimated by the statistical image analyses of elemental microprobe maps and back-scattered electron (BSE) images. Element mapping shows that most of the daughter minerals in the inclusions are homogeneous and have no significant compositional zoning (Fig. 5). Exposed areas in random cross-sections may incorrectly represent volume proportions and real modes, however, average values for multiple inclusions should be representative, at least at semi-quantitative level. Some typical results of the modal calculations are presented in Table 3 and the whole data set is listed in Appendix I. The inclusions show large compositional variations reflecting the scatter in modal proportions. $\mathrm{SiO}_{2}$ contents of the inclusions vary from 20.79 wt. $\%$ to 50.16 wt. $\%$, $\mathrm{FeO}_{\text {t }}$ from 13.44 wt. $\%$ to 32.78 wt. $\%$ and $\mathrm{Al}_{2} \mathrm{O}_{3}$ from 10 wt. $\%$ to 21.17 wt. $\%$. $\mathrm{K}_{2} \mathrm{O}$ and $\mathrm{Na}_{2} \mathrm{O}$ contents vary by a factor of $2-4$, but alkali totals are relatively low and do not exceed a few weight percent.

It can be stated that the bulk compositions of the inclusions correspond to hydrated aluminosilicate melts, which are strongly enriched in iron, strongly depleted in silica, high in $\mathrm{MgO}$ and alumina, and low in alkalis and $\mathrm{CaO}$. Estimations of the bulk $\mathrm{CaO}$ content of the inclusions are further complicated by the fact that some apatite must have crystallised on the inclusion walls during post-entrapment cooling and crystallisation but the exact amount is unknown. Nevertheless, the variation diagrams in the Fig. 6 imply a continuous compositional variability for the majority of the inclusions along a poorly defined trend, i.e. with decreasing silica content, the 
melt shows an enrichment of $\mathrm{Mg}$ and Fe whereas an decrease of alkalis content, and extremely low content of $\mathrm{Ca}$.

\section{2) Homogenized melt inclusion}

In order to estimate more accurately bulk melt compositions of single inclusions we also performed heating experiments on the apatite single crystals in the temperature range of $1100-1200^{\circ} \mathrm{C}$. All the inclusions which had been heated at $1100^{\circ} \mathrm{C}$ and $1150^{\circ} \mathrm{C}$ and $200 \mathrm{MPa}$ are not unexpectedly homogenised (Fig. 7a-d). These inclusions are composed of partial melts, olivine, plagioclase, K-feldspar, chlorite, mica, quartz and minor clinopyroxene. Examples of the typical products of heating experiments are shown in Table 4. Daughter crystal phases start to melt noticeably at $1150^{\circ} \mathrm{C}$ and completely homogenized at $1200^{\circ} \mathrm{C}$ (Fig. 7e and f). In theory, the high temperature may arise either from heterogeneous trapping of crystals with the melt pocket or from post-entrapment modification of the inclusions. Those inclusions in which clinopyroxene and/or oxide microphenocrysts were trapped along with the melt droplets should show anomalously high homogenization temperatures or retain excess pyroxene or oxides as undissolved crystals in partly homogenized inclusions.

Electron microprobe analyses of glasses in completely homogenized melt inclusions show significant variations in major element compositions. $\mathrm{SiO}_{2}$ contents vary from 30 to 44 wt. $\%, \mathrm{FeO}_{\text {t }}$ from 8 to 21 wt. $\%$ and $\mathrm{Al}_{2} \mathrm{O}_{3}$ from 5 wt. $\%$ to 16 wt. \% (Table 4; Fig. 6). The high homogenization temperatures of the melt inclusions 
imply excessive melting of the host apatite. However, these compositions display similar characteristics with those estimated using modal abundances except for $\mathrm{CaO}$ (12-23 wt.\%; Fig. 6d) and $\mathrm{P}_{2} \mathrm{O}_{5}$ (7-12 wt.\%; Table 4). In comparison, the partial melt in the un-homogenized inclusions $\left(1100-1150^{\circ} \mathrm{C}\right)$ contain more elements that are relatively incompatible in the co-existing mineral phases, i.e. lower $\mathrm{Mg}$ but higher $\mathrm{K}$ and $\mathrm{Si}$. These partial melts display similar $\mathrm{Fe}, \mathrm{Al}$ and $\mathrm{Na}$ content with the homogenized ones (Fig. 6).

\subsection{Composition of host apatite}

All the apatite crystals analyzed in this study are relatively F-rich and Cl-poor (Table 5 and Appendix II), which is consistent with high-temperature magmatic crystallisation (Tacker and Stormer, 1989). The concentrations of F are more variable in the apatite from the anorthosite and melanorite (1.57-3.94 wt. \%) compared with those from the nelsonite (3.46-3.91 wt. \%). Specifically, values of $\mathrm{X}_{\mathrm{F}}$ [= molecular $\mathrm{F} /(\mathrm{F}+\mathrm{Cl})]$ range from 0.82 to 0.99 in anorthosite and melanorite, but values of $\mathrm{X}_{\mathrm{F}}$ in nelsonite keep up 0.98 to 0.99 (Fig. 8).

\subsection{Whole rock compositions}

Whole rock major and trace elements compositions of nelsonite, anorthosite and melanorite are listed in Appendix III and shown in Fig. 9. The rare earth element (REE) concentrations in the three types of whole rocks are highly variable $\left(\mathrm{La}_{\mathrm{N}} \sim 13-435 \times\right.$ chondrites, $\mathrm{Lu}_{\mathrm{N}} \sim 0-36 \times$ chondrites$)$ and the $(\mathrm{La} / \mathrm{Yb})_{\mathrm{N}}$ ratios are variably 
from 8.66 to 25.5 , but the pattern shapes are remarkably parallel in each case. The anorthosite samples have prominent positive $\mathrm{Eu}$ anomalies, whereas the nelsonite samples have slightly negative Eu anomalies (Fig. 9). Similar REE patterns of anorthosite, nelsonite and melanorite were reported by Zhao et al. (2009). As should be expected for a rock with high modes of cumulus apatite, the REE concentrations of the nelsonites are much higher than those of the other two types of rocks. The concentrations of $\mathrm{Cs}, \mathrm{Rb}, \mathrm{Ba}$ and $\mathrm{Sr}$ in the nelsonite are much lower than those in anorthosite and melanorite.

\section{Discussion}

Apatite-magnetite rocks in magmatic intrusions are classified in two major groups: (1) high-Ti nelsonites (Dill et al., 2010) and (2) low-Ti Kiruna-type ores (Nystroem and Henríquez, 1994). Origin by liquid immiscibility has been proposed for both but chemical compositions of the presumed immiscible Fe-P-rich melts differ strongly between the groups. The Kiruna-type deposits are believed to have formed from sulphide-sulphate-phosphate Fe-S-O-P melt with the $\mathrm{O} / \mathrm{S}$ molar ratio greater than 1.3 (Henríquez et al., 2003). The existence of the Fe-S-O immiscible melts with low $\mathrm{Ti}$ and Si contents at relevant magmatic temperatures has been well documented experimentally (Lester et al., 2013). Damiao ores clearly belong to the Ti-rich group of nelsonites where sulphur does not seem to be a major component of parental melt.

Model compositions of parental melts for nelsonites in massif anorthosite complexes have been either ordinary aluminosilicate dacitic-andesitic melts (Charlier 
et al., 2006) or immiscible magnetite-apatite liquids (Chen et al., 2013; Philpotts, 1967; Reynolds, 1985). Here we show that the latter type of liquid, especially the composition recently proposed by Chen et al. (2013), is not reliable as evidenced by melting experiments and the compositions of melt inclusions in apatite from Damiao nelsonite deposits.

\subsection{Melting temperature and phase equilibria constraints}

The results of our DSC study show that the one-third apatite and two-thirds Fe-Ti oxides by weight, completely melts well above $1450{ }^{\circ} \mathrm{C}$ (Fig. 3). Even with presence of considerable amount of volatiles, i.e. $\mathrm{H}_{2} \mathrm{O}$ and $\mathrm{F}$, nelsonitic liquid still does not melt at temperatures up to $1200^{\circ} \mathrm{C}$ (Table 2). Thus, the composition is too refractory and cannot be molten at temperatures relevant for crystallisation of the Damiao magma.

Our experimental studies at dry condition imply high liquidus temperature of the model nelsonite composition are in good agreement with numerous experimental studies of the $\mathrm{CaO}-\mathrm{P}_{2} \mathrm{O}_{5}-\mathrm{Fe}_{\mathrm{x}} \mathrm{O}$ system at variable, mostly reducing redox conditions carried out for metallurgical applications. Phase equilibria in the system have been extensively studied because of their importance for metallurgical slags and phosphorus removal from molten metal in steel making. According to the metallurgical papers (Hasegawa et al., 2003; Kalita et al., 2004; Kaida et al., 2005; Gao et al., 2012; Trömmel et al., 1961), liquidus temperature of the anhydrous nelsonite composition proposed by Chen et al. (2013) should be well above $1400{ }^{\circ} \mathrm{C}$, 
although the exact liquidus temperature has not been determined.

Proponents of immiscible apatite-magnetite nelsonite melts usually refer to an experimental study by Philpotts (1967), in which the existence of such melts in natural magmas has been claimed for the first time. Philpotts (1967) estimated the apatite-magnetite eutectic temperature at about $1420{ }^{\circ} \mathrm{C}$ and acknowledged the fact that the temperature was too high for nelsonite crystallisation in natural magmatic systems. He proposed that volatile components, which were absent from his experimental charges, and fluorine in particular, could have significantly lowered the liquidus temperature. However, our IPHV melting experiments show that the presence of considerable amount of $\mathrm{H}_{2} \mathrm{O}$ and $\mathrm{F}$ is not able to lower the magnetite-apatite eutectic temperature by $200-300{ }^{\circ} \mathrm{C}$ (Table 2). This is attributed to extremely high melting temperature of F-apatite $\left(1660^{\circ} \mathrm{C}\right.$; Packter and Doherty, 1989), which is even higher than the melting temperature of volatile-free Ca phosphate $\left(1470{ }^{\circ} \mathrm{C}\right.$; Millet et al., 1983). Besides, although water is undoubtedly able to lower the liquidus temperature of the system, in this case, it is obviously still not enough to cause the melting of nelsonite in magmatic system. In summary, our experiments show that in the volatile-rich system, the melting point of the nelsonite does not decrease as expected and still is higher than the liquidus of the usual basaltic melt. Hence, such "nelsonitic" melt probably does not exist in the magmatic system.

The schematic pseudo-ternary phase diagram published by Philpotts (1967) was based on a series of isothermal runs at $1420^{\circ} \mathrm{C}$ in air (Fig. 10a). At this temperature, the diagram implies the existence of a broad miscibility gap between a silicate melt of 
ferrodioritic composition, apatite liquid and magnetite-apatite (nelsonite) melt. In Fig. $10 \mathrm{~b}$ we plot electron microprobe analyses of immiscible melts in multicomponent Fe-rich silicate and phosphate-silicate experimental systems, and compositions of immiscible glasses in natural volcanic rocks using the same pseudo-ternary projection as in the original Philpotts diagram (Fig. 10a). The compositions vary broadly with temperature, redox conditions and bulk magma chemistry but, importantly, all the liquids on the Fe- and P-rich side of the miscibility gap have at least $20 \mathrm{wt}$ \% of aluminosilicate components. In immiscible silica-rich compositions which are most relevant for Damiao anorthosites (e.g., Philpotts, 1981), the silicate content in the conjugate Fe-rich immiscible melt is no less than 40 wt. \%. Therefore, silica-free immiscible Ca-Fe-Ti-P nelsonite melts have been supported neither by electron microprobe analyses of experimental products nor by natural volcanic analogues.

In Fig. 11 the apatite-silicate boundary join of the pseudo-ternary diagram is compared with similar pseudo-binary apatite-alumionsilicate joins studied by Kogarko (1971) and Kriman and Krot (1992). Comparison of the plots shows that apatite liquidus is positioned much lower in the apatite-diorite join as implied by Philpotts (1967) in disagreement with the later studied systems. The dramatic drop of apatite liquidus by more than $200{ }^{\circ} \mathrm{C}$ with the addition of just a few weight percent of aluminosilicate components implied by Fig. 11a and 11d is not supported by other studies and seems to us unlikely. In summary, we believe that silica-free apatite-nelsonite immiscible melts are not supported by solid experimental evidence.

\subsection{Evidence from melt inclusions and bulk rocks}




\subsubsection{Origin of the melt inclusions: a record of the evolution of late-stage intercumulus melt}

Field relations show that the nelsonite formed later than the anorthosite which crystallized from an anhydrous high-Al basaltic melt (c.f. He et al., 2016). This suggests us the melt inclusions only record the late-stage evolution of the magma when nelsonite precipitated. Hydrous, low-tempeyib

rature minerals (e.g., chlorite) cannot be trapped by F-rich, magmatic apatite as solid inclusions. Low-temperature minerals must have formed inside apatite crystals after the entrapment, either by closed-system crystallisation of the trapped hydrated late-stage melt, or by open-system interaction with external, possibly post-magmatic fluid. Visible cracks or fissures, which would open the inclusions to external fluids, are often absent around the inclusions (Figs. 4 a-f), implying that the low-temperature alteration of the inclusions by external fluids is unlikely. Furthermore, apatite crystals in nelsonite, which host the inclusions, are low in $\mathrm{Cl}$ (Fig. 9) and have high $\mathrm{F} / \mathrm{Cl}$ values even in comparison with apatite from anorthosite and norite. The morphology and composition of apatite crystals in nelsonite both imply magmatic origin and give no signs of hydrothermal alteration (Webster and Piccoli, 2015). Therefore, we favour the formation of hydrated daughter silicate minerals in the apatite-hosted inclusions by closed-system crystallisation of late-stage hydrated melt.

Nevertheless, the homogenisation temperature of the inclusions, i.e. $\sim 1200^{\circ} \mathrm{C}$, is even higher than the liquidus temperature of most basaltic magma in general. At this temperature and pressure, excessive amount of apatite dissolved into the melting inclusions. This again strongly indicates that these inclusions do not represent a 
primary but a late-stage melt. Furthermore, these hydrated melts are not normal magma (e.g., Toplis and Carroll, 1996; Namur et al., 2012) but a quite refractory composition even with a volatile-rich affinity, corresponding to the low content of $\mathrm{Si}$, $\mathrm{Ca}, \mathrm{P}, \mathrm{Na}$, and $\mathrm{K}$, and high contents of $\mathrm{Fe}, \mathrm{Mg}$ and aqueous fluids. If this is the case, it appears that some additional mechanism must have been responsible for the further significant depletion of the Fe-rich melt in alkalis, $\mathrm{Ca}$ and $\mathrm{Si}$ during the late-stage evolution of the magma. The hydrated nature of the inclusions and the fact that the depleted components are highly soluble in hydrothermal fluids (Bai and Groos, 1999) lead us to suggest that the depleted components may have been removed by exsolution of a magmatic hydrous fluid phase. For effective depletion, the fluid should coexist with the Fe-rich silicate melt or two immiscible silicate liquids at the time of apatite crystallisation and the fluid-to-melt mass ratio should be sufficiently high.

\subsubsection{Interaction between fluids and an immiscible Fe-rich melt}

As discussed in the introduction section, silicate liquid immiscibility is a popular hypothesis of the nelsonite origin. In the case of Damiao, high REE values both in nelsonite and apatite (Fig. 9) coexist with high values of $\mathrm{Cr}$ in magnetites are in a support of this model (Chen et al., 2013; Duchesne and Liégeois, 2015; He et al., 2016). Previous studies of apatite-hosted melt inclusions in the Skaergaard, Sept-Iles and Bushveld intrusions (Fig. 12a, Jakobsen et al., 2005; Charlier et al., 2011; Fischer et al., 2016) revealed two contrasting types of inclusion compositions, Fe-rich and 
silica-rich, and thus provided strong evidence supporting liquid immiscibility in those intrusions. At Damiao, the homogenized Fe-rich inclusions show quite similar signatures with those immiscible Fe-rich melt inclusions previously found in Skaergaard, Sept Iles and especially Bushveld (Fig.12), in terms of the $\mathrm{CaO} / \mathrm{Al}_{2} \mathrm{O}_{3}$ and $\mathrm{SiO}_{2} / \mathrm{Al}_{2} \mathrm{O}_{3}$ ratios. The $\mathrm{CaO} / \mathrm{Al}_{2} \mathrm{O}_{3}$ ratio is typically high in immiscible Fe-rich liquids because of the contrasting liquid-liquid $\mathrm{Ca}$ and $\mathrm{Al}$ partitioning (e.g., Watson, 1976; Dixon and Rutherford, 1979; Philpotts, 1982; Veksler et al., 2006, 2007). However, both modal estimation $(6.5-26 \mathrm{wt} . \% \mathrm{MgO})$ and the composition obtained by re-homogenization experiments (7-19 wt.\% $\mathrm{MgO})$ are considerably higher in $\mathrm{MgO}$ (Tables 3 and 4) compared to those of the three intrusions. This could be explained by the interaction between a magmatic hydrous fluid phase and the immiscible Fe-rich melt, which is also capable to account for the low $\mathrm{Ca}$ and alkalis contents in the inclusions (Fig. 5).

In summary, silicate liquid immiscibility probably occurred during the early stage of the magmatic evolution, i.e. before the arrival of aqueous fluids and the precipitation of nelsonite. Silicate liquid immiscibility and fractionation of the silica-rich immiscible liquid may have contributed to the extreme $\mathrm{Fe}$ - and P-enrichment of the nelsonite (He et al., 2016).

Moreover, the interaction between the aqueous fluids and the crystalizing immiscible Fe-rich melts could also have other effects, i.e. crystal-melt and fluid-melt equilibria apparently have played important or even greater roles in this unusual magma evolution trend evidenced by the melt inclusions. For example, high contents 
of aqueous fluids in the late-stage melt may have also affected the plagioclase stability and caused partial dissolution of some cumulus plagioclase. Plagioclase resorption may have elevated the alumina concentration in the Fe-rich late-stage melt and, as discussed below, may have affected the whole rock REE patterns.

\subsubsection{Evidence from bulk rocks}

The whole rock samples of nelsonite and the separate apatite show close similarity in REE patterns. The total REE concentrations of apatite/nelsonite vary by a factor of 2-4, and the depletion of $\mathrm{Cs}, \mathrm{Rb}, \mathrm{Ba}$ and $\mathrm{Sr}$ in nelsonite (Fig. 9a and b) suggest the nelsonites are cumulates of Fe-Ti oxide and apatite, as described in Chen et al. (2013). It is worth pointing out that Eu anomalies are absent from the nelsonites in the Maying district. This is surprising, since apatite accepts the trivalent REE into its structure but exclude the larger $\mathrm{Eu}^{2+}$. Two following reasons are considered generally. One is the parental melt possessed a positive Eu anomaly. However, the Damiao anorthosite shows strongly Eu positive anomaly, suggesting the existence of extensive plagioclase accumulation. As stated above, the nelsonites are more evolved than the anorthosites, so obvious negative Eu anomalies should be expected. Another alternative explanation is that due to high $f_{\mathrm{O} 2}$ conditions of the melt, most of $\mathrm{Eu}^{2+}$ would be changed into $\mathrm{Eu}^{3+}$ (Dymek and Owens, 2001). However, the partitioning coefficient of both $\mathrm{Eu}^{2+}$ and $\mathrm{Sr}^{2+}$ are low in apatite, compared with trivalent $\mathrm{REE}$ (Watson and Green, 1981; Bedard, 2001; Prowatke and Klemme; 2006). Sr still shows strongly relative depletion in the nelsonite, which is not unanimous with the absence 
of Eu depletion. Moreover, the highly oxidizing conditions will also result in the high $\mathrm{Fe}_{2} \mathrm{O}_{3}$ content in the melt, strongly affected the Fe-Ti oxide into hemo-ilmenite. This is not concordant with the observation of large abundances of titanomagnetite in the Damiao nelsonite.

Experimental studies showed the two-liquid partition coefficients of REE are more than three times greater in $\mathrm{P}_{2} \mathrm{O}_{5}$-bearing immiscible melts than in $\mathrm{P}_{2} \mathrm{O}_{5}$-free melts (Watson, 1976; Ryerson and Hess, 1980). Nevertheless, we still do not know exactly the partition coefficients of REE for the Fe-P-rich melt that contains considerable amounts of $\mathrm{H}_{2} \mathrm{O}$. Local dissolution of plagioclase can result from compaction during post-cumulus growth, owing to dissolution of unfavourably oriented plagioclase and reprecipitation of the material in lower stress orientations (Humphrey, 2011), as suggested for the Stillwater Intrusion (Meurer and Boudreau, 1998) and the Skaergaard Intrusion (Boudreau and McBirney, 1997). We consider the absence of $\mathrm{Eu}$ anomalies of nelsonites to represent dissolution of cumulus plagioclase in the intercumulus melt from which apatite crystallised.

Moreover, as stated above, the hydrated nature of the inclusions indicates presence of aqueous fluids in the immiscible Fe-rich melts during the late-stage evolution. Hence, except fractional crystallisation of plagioclase and apatite, we would also predict the removal of soluble elements (e.g. $\mathrm{Ca}, \mathrm{Al}$ ) by aqueous fluid migration. LILEs like $\mathrm{Ba}$ and $\mathrm{Sr}$ are easier partitioned into aqueous fluids (Kelemen et al., 2003; Castillo and Newhall, 2004), and consequently removed by aqueous fluids transportation. The combined effects of aqueous fluids and resorption of plagioclase 
are thus the most convincing explanation to the absence of Eu anomalies and high $\mathrm{Al}$ contents of the melt, as well as the features of $\mathrm{Ba}$, Sr depletion and low Ca contents.

\subsection{Implications for origin of the nelsonite}

The results of this study lead us to propose that nelsonites are cumulates from an immiscible Fe-rich fractionated melt. The residual melt of the anorthosite follow iron-enrichment because of plagioclase subtraction. Iron-enrichment will promote liquid immiscibility (Charlier and Grove, 2012) and the cooling residual melt reach a two-liquid field. The immiscible Fe-rich melt that is produced will fractionate and crystallize abundant cumulus Fe-Ti oxides and apatite that will form cumulates of nelsonitic composition. Our model also emphasis on the late migration of a hydrothermal fluid phase in these melts which is expected to cause the significant losses of more water-soluble alkali and Ca silicate components from the melt into the fluid. This process is capable to remove the depleted components, i.e. alkali, Si and $\mathrm{Ca}$, and favourable to precipitate nelsonite (Fig. 12). The model of extensive fluid migration during the late-stage evolution is also supported by the alteration of the Damiao anorthosite, i.e. the plagioclase is replaced into albite and clinozoisite (Li et al., 2014).

\section{Conclusions}

The 'nelsonitic liquid' does not melt at the temperature up to $1200{ }^{\circ} \mathrm{C}$ with presence of considerable amount of volatiles, e.g., fluorine and water. Analyses of the 
apatite-hosted melt inclusions in Damiao nelsonite show hydrated signature and extremely low $\mathrm{Ca}$ and alkalis, and significantly differ from those of the typical immiscible Fe-rich melts despite the high Fe content and low silica. We propose that the inclusions at Damiao record a trend of intercumulus melt evolution, which have been through liquid-liquid immiscibility but most likely have been strongly affected by separation of a hydrothermal fluid phase and the losses of alkali and Ca silicate components from the melt into the fluid.

\section{Acknowledgements}

We thank Oona Appelt for the microprobe analysis in Helmholtz Centre Potsdam GFZ German Research Centre for Geosciences. Parts of this work were supported by 973 Project (Grant No. 2012CB416806) and China Postdoctoral Science Foundation funded project (2016M590118). IVV acknowledges support by Russian Science Foundation, grant No. 14-17-00200. TH acknowledges support by a Marie Curie Individual Fellowship within the Horizon 2020 - Research and Innovation Framework Programme (656923), China Nature Foundation of Sciences (41502052) and the "Fundamental Research Funds for the Central Universities (2652015054)".

\section{References}

Alva-Valdivia LM, Rivas ML, Goguitchaichvili A, Urrutia-Fucugauchi J, González JA, Morales J, Gómez S, Henríquez, F, Nyström JO, Naslund RH (2003) 
Rock-magnetic and oxide microscopic studies of the El Laco iron ore deposits, Chilean Andes, and implications for magnetic anomaly modelling. Int Geol Rev 45: 533-547

Bai, T. B. and Koster van Groos, A. F. (1999). The distribution of Na, K, Rb, Sr, Al, Ge, $\mathrm{Cu}, \mathrm{W}, \mathrm{Mo}, \mathrm{La}$, and $\mathrm{Ce}$ between granitic melts and coexisting aqueous fluids. Geochimica et Cosmochimica Acta 63(7), 1117-1131.

Bedard, J.H. (2001). Parental magmas of the Nain Plutonic Suite anorthosites and mafic cumulates: a trace element modelling approach. Contributions to Mineralogy and Petrology 141(6), 747-771.

Berndt, J., Liebske, C., Holtz, F., Freise, M., Nowak, M., Ziegenbein, D., Hurkuck, W., Koepke, J. r. (2002). A combined rapid-quench and $\mathrm{H}_{2}$-membrane setup for internally heated pressure vessels: Description and application for water solubility in basaltic melts. American Mineralogist 87, 1717-1726.

Bogaerts, M., and Schmidt, M. W. (2006). Experiments on silicate melt immiscibility in the system Fe2SiO4-KAlSi3O8-SiO2-CaO-MgO-TiO2-P2O5 and implications for natural magmas. Contributions to Mineralogy and Petrology, 152(3), 257-274.

Boudreau, A. E., and McBirney, A. R. (1997). The Skaergaard layered series. Part III. Non-dynamic layering. Journal of Petrology, 38(8), 1003-1020.

Cao, Y. W. (1988). Research on the genesis of Damiao anorthosite an hosted Fe-P deposit. Thesis for Master's Degree, Chines Academy of Earth Science, Beijing, China (in Chinese).

Castillo, P. R., and Newhall, C. G. (2004). Geochemical constraints on possible subduction components in lavas of Mayon and Taal volcanoes, southern Luzon, Philippines. Journal of Petrology, 45(6), 1089-1108.

Charlier, B., and Grove, T. L. (2012). Experiments on liquid immiscibility along tholeiitic liquid lines of descent. Contributions to Mineralogy and Petrology 164(1), 27-44.

Charlier, B., Duchesne, J. C., Vander Auwera, J. (2006). Magma chamber processes in the Tellnes ilmenite deposit (Rogaland Anorthosite Province, SW Norway) and the formation of $\mathrm{Fe}-\mathrm{Ti}$ ores in massif-type anorthosites. Chemical Geology, 234(3), 264-290.

Charlier, B., Sakoma, E., Sauvé, M., Stanaway, K., Vander Auwera, J., Duchesne, J.-C., 2008. The Grader layered intrusion (Havre-Saint-Pierre Anorthosite, Quebec) and genesis of nelsonite and other Fe-Ti-P ores. Lithos 101, 359-378.

Charlier, B., Namur, O., Grove, T.L., 2013. Compositional and kinetic controls on liquid immiscibility in ferrobasalt-rhyolite volcanic and plutonic series. Geochimica et Cosmochimica Acta 113, 79-93.

Charlier, B., Namur, O., Bolle, O., Latypov, R. and Duchesne, J.C., (2015). Fe-Ti-V-P ore deposits associated with Proterozoic massif-type anorthosites and related rocks. Earth-Science Reviews, 141, pp.56-81.

Charlier, B., Namur, O., Toplis, M. J., Schiano, P., Cluzel, N., Higgins, M. D. and Vander Auwera, J. (2011). Large-scale silicate liquid immiscibility during differentiation of tholeiitic basalt to granite and the origin of the Daly gap. 
Geology 39, 907-910.

Chen, W. T., Zhou, M. F. and Zhao, T. P. (2013). Differentiation of nelsonitic magmas in the formation of the $\sim 1.74 \mathrm{Ga}$ Damiao Fe-Ti-P ore deposit, North China. Contributions to Mineralogy and Petrology 165, 1341-1362.

Darling, R. S. and Florence, F. P. (1995). Apatite light rare earth element chemistry of the Port Leyden nelsonite, Adirondack Highland, New York: implications for the origin of nelsonite in anorthosite suite rocks. Economic Geology 90, 964-968.

Dill, H. G. (2010). The "chessboard" classification scheme of mineral deposits: mineralogy and geology from aluminum to zirconium. Earth-Science Reviews, 100, $1-420$.

Dixon, S., and Rutherford, M. J. (1979). Plagiogranites as late-stage immiscible liquids in ophiolite and mid-ocean ridge suites: an experimental study. Earth and Planetary Science Letters, 45(1), 45-60.

Duchesne, J.-C., Liégeois, J.-P., (2015). The origin of nelsonite and high-Zr ferrodiorite associated with Proterozoic anorthosite. Ore Geology Reviews 71, 40-56.

Dymek, R. F., and Owens, B. E. (2001). Petrogenesis of apatite-rich rocks (nelsonites and oxide-apatite gabbronorite) associated with massif anorthosite. Economic Geology 96, 797-815.

Eales, H. V. and Cawthorn, R. G. (1996). The Bushveld Complex. Developments in Petrology 15, 181-229.

Emslie, R. F. (1978). Anorthosite massifs, rapakivi granites, and late Proterozoic rifting of North America. Precambrian Research 7(1), 61-98.

Fenner, C. N. (1929). The crystallisation of basalts. American Journal of Science, 18, 225-253.

Fischer, L. A., Wang, M., Charlier, B., Namur, O., Roberts, R. J., Veksler, I. V., Cawthorn, R.G., Holtz, F. (2016). Immiscible iron-and silica-rich liquids in the Upper Zone of the Bushveld Complex. Earth and Planetary Science Letters, 443, 108-117.

Force, E. R. (1991). Geology of titanium-mineral deposits (Vol. 259). Geological Society of America.

Gaetani, G. A., and Grove, T. L. (1998). The influence of water on melting of mantle peridotite. Contributions to Mineralogy and Petrology, 131(4), 323-346.

Gao, X., Matsuura, H., Sohn, I., Wang, W., Min, D. J. and Tsukihashi, F. (2012). Phase Relationship of $\mathrm{CaO}-\mathrm{SiO}_{2}-\mathrm{FeO}-5$ mass pct $\mathrm{P}_{2} \mathrm{O}_{5}$ System with Low Oxygen Partial Pressure at $1673 \mathrm{~K}\left(1400^{\circ} \mathrm{C}\right)$. Metallurgical and Materials Transactions B 43(4), 694-702.

Goldberg, S. (1984). Geochemical relationships between anorthosite and associated iron-rich rocks, Laramie Range, Wyoming. Contributions to Mineralogy and Petrology 87, 376-387.

Hageskov, B., and Pedersen, S. (1986). The petrology of a metamorphosed netveined acid-basic intrusion from the Østfold area, southeast Norway.Precambrian research, 32(4), 317-341.

Hall, L. J., Brodie, J., Wood, B. J., Carroll, M. R. (2004). Iron and water losses from 
hydrous

Hasegawa, M., Iwase, M., Wakimoto, K. and McLean, A. (2003). A thermochemical study of the $\mathrm{CaO}+\mathrm{P}_{2} \mathrm{O}_{5}+\mathrm{Fe}_{\mathrm{x}} \mathrm{O}$ system regions in equilibrium with solid $\mathrm{Ca}_{3} \mathrm{P}_{2} \mathrm{O}_{8}$. Scandinavian journal of metallurgy 32(1), 47-52.

He H. L., Yu S. Y., Song X. Y, Du Z. S., Dai Z. H., Zhou T., Xie W. (2016). Origin of nelsonite and Fe-Ti oxide ore of the Damiao anorthosite complex, NE China: Evidence from trace element geochemistry of apatite, plagioclase, magnetite and ilmenite. Ore Geology Reviews. doi: 10.1016/j.oregeorev.05.028

Henríquez, F., Naslund, H. R., Nyström, J. O., Vivallo, W., Aguirre, R., Dobbs, F. M., and Lledó, H. (2003). New field evidence bearing on the origin of the El Laco magnetite deposit, northern Chile-a discussion. Economic Geology 98(7), 1497-1500.

Hou, T., and Veksler, I. V. (2015). Letter. Experimental confirmation of high-temperature silicate liquid immiscibility in multicomponent ferrobasaltic systems. American Mineralogist, 100(5-6), 1304-1307.

Humphreys, M. C. (2011). Silicate liquid immiscibility within the crystal mush: evidence from $\mathrm{Ti}$ in plagioclase from the Skaergaard intrusion. Journal of Petrology, 52(1), 147-174.

Jakobsen, J. K., Veksler, I. V., Tegner, C. and Brooks, C. K. (2005). Immiscible ironand silica-rich melt in basalt petrogenesis documented in the Skaergaard intrusion. Geology 33, 885-888.

Jakobsen, J. K., Veksler, I. V., Tegner, C. and Brooks, K. (2011). Crystallisation of the Skaergaard intrusion from an emulsion of immiscible ironand silica-rich liquids: evidence from melt inclusions in plagioclase. Journal of Petrology 52, 345-373.

Kägi, R., Müntener, O., Ulmer, P., Ottolini, L. (2005). Piston-cylinder experiments on $\mathrm{H} 2 \mathrm{O}$

Kaida, Y., Hasegawa, M., Iwase, M., Kikuchi, Y. and Wakimoto, K. (2005). A new experimental technique for determinations of the activities of $\mathrm{P}_{2} \mathrm{O}_{5}$ and $\mathrm{Fe}_{\mathrm{x}} \mathrm{O}$-the system $\mathrm{CaO}-\mathrm{P}_{2} \mathrm{O}_{5}-\mathrm{Fe}_{\mathrm{x}} \mathrm{O}$. Metallurgical and Materials Transactions B 36(1), 43-51.

Kalita, S. J., Bose, S., Hosick, H. L., and Bandyopadhyay, A. (2004). $\mathrm{CaO}-\mathrm{P}_{2} \mathrm{O}_{5}-\mathrm{Na}_{2} \mathrm{O}$-based sintering additives for hydroxyapatite (HAp) ceramics. Biomaterials 25(12), 2331-2339.

Kamenetsky, V.S., Charlier, B., Zhitova, L., Sharygin, V., Davidson, P., Feig, S., (2013). Magma chamber-scale liquid immiscibility in the Siberian Traps represented by melt pools in native iron. Geology 41, 1091-1094.

Kelemen, P. B., Hanghøj, K., and Greene, A. R. (2003). One view of the geochemistry of subduction-related magmatic arcs, with an emphasis on primitive andesite and lower crust. Treatise on geochemistry, 3, 593-659.

Kogarko, L. N., Krigman, L. D., and Belyakova, Y. (1984). The nepheline-diopside-apatite system and liquid evolution during the crystallization of an apatite-bearing ijolite-urtite magma. Geochemistry International, 21(4), 38-58.

Kogarko, L.N. (1971). Geokhimiya 2, 160 (in Russian).

Kolker, A. (1982). Mineralogy and geochemistry of Fe-Ti oxides and apatite (nelsonite) 
deposits and evaluation of the liquid immiscibility hypothesis. Economic Geology 77, 1146-1158.

Krigman, L. D. and Krot, T. V. (1992). Stable Phosphate-Silicate Immiscibility in Magmas. Geochemistry international C/C of Geokhimiia 29, 28-28.

Lester, G. W., Clark, A. H., Kyser, T. K., and Naslund, H. R. (2013). Experiments on liquid immiscibility in silicate melts with $\mathrm{H} 2 \mathrm{O}, \mathrm{P}, \mathrm{S}, \mathrm{F}$ and $\mathrm{Cl}$ : implications for natural magmas. Contributions to Mineralogy and Petrology, 166(1), 329-349.

Li, H. K., Li, H. M. and Lu, S. N. (1995). Grain zircon U-Pb ages for volcanic rocks from Tuanshanzi Formation of Changcheng system and their geological implications. Geochimica 24, 43-48 (in Chinese with English abstract).

Li, Houmin, Lixing Li, Zhaochong Zhang, M. Santosh, Mingjun Liu, Yanhe Cui, Xiuqing Yang, Jing Chen, Tong Yao. (2014). Alteration of the Damiao anorthosite complex in the northern North China Craton: Implications for high-grade iron mineralization. Ore Geology Reviews, 57, 574-588.

Liu, D. Y., Nutman, A. P., Compston, W., Wu, J. S. and Shen, Q. H. (1992). Remnants of $\geq 3800$ Ma crust in the Chinese part of the Sino-Korean Craton. Geology 20, 339-342.

Liu, S. W., Lu, Y. J., Feng, Y. G., Zhang, C., Tian, W., Yan, Q. R. and Liu, X. M. (2007). Geology and zircon U-Pb isotopic chronology of Dantazi complex, northern Hebei Province. Geological Journal of China Universities 13, 484-497 (in Chinese with English abstract).

McDonough, W.F. and Sun, S. S. (1995). The composition of the Earth. Chemical Geology 120(3), 223-253.

McLelland, J., Ashwal, L. and Moore, L. (1994). Composition and petrogenesis of oxide-, apatite-rich gabbronorites associated with Proterozoic anorthosite massifs: examples from the Adirondack Mountains, New York. Contributions to Mineralogy and Petrology 116, 225-238.

Meurer, W. P., and Boudreau, A. E. (1998). Compaction of igneous cumulates. Part I. Whole-rock compositions as an indicator of the trapped liquid proportions in the Stillwater complex, Montana. J Geol, 106, 281-292.

Microvolumes Applying the Model "PAP". Electron Probe Quantitation: Springer US, 31- 75.

Millet, J. M., Sassoulas, R., and Sebaoun, A. (1983). Transitions solide $\rightleftharpoons$ solide dans le systeme $\mathrm{CaO}-\mathrm{Na}_{2} \mathrm{O}-\mathrm{P}_{2} \mathrm{O}_{5}$; sous-systeme $\mathrm{Ca}_{3}\left(\mathrm{PO}_{4}\right)_{2}-\mathrm{CaNaPO}_{4}$. Journal of thermal analysis 28(1), 131-146.

Namur, O., Charlier, B. and Holness, M. B. (2012). Dual origin of Fe-Ti-P gabbros by immiscibility and fractional crystallisation of evolved tholeiitic basalts in the Sept Iles layered intrusion. Lithos 154, 100-114.

Namur, O., Charlier, B., Pirard, C., Hermann, J., Liégeois, J. P. and Vander Auwera, J. (2011). Anorthosite formation by plagioclase flotation in ferrobasalt and implications for the lunar crust. Geochimica et Cosmochimica Acta 75(17), 4998-5018.

Namur, O., Charlier, B., Toplis, M. J., Higgins, M. D., Liégeois, J. P. and Vander Auwera, J. (2010). Crystallisation sequence and magma chamber processes in the 
ferrobasaltic Sept Iles layered intrusion, Canada. Journal of Petrology 51(6), 1203-1236.

Naslund, H. R. (1983). The effect of oxygen fugacity on liquid immiscibility in iron-bearing silicate melts. American Journal of Science 283, 1034-1059.

Naslund, H., Mungall, J., Henríquez, F., Nyström, J., Lledó, H., Lester, G., and Aguirre, R. (2009). Melt inclusions in silicate lavas and iron-oxide tephra of the El Laco volcano, Chile. Santiago 22, S8_033.

NGB-HGMEB (No.4 Geological Brigade of Hebei Geology and Mineral Exploration Bureau) (1986) Research report on the Geology and genesis of the Damiao anorthosite complex and hosted V-Ti magnetite-apatite deposits, Chengde, Hebei Province, 1-681 (in Chinese).

Nystroem, J. O., and Henríquez, F. (1994). Magmatic features of iron ores of the Kiruna type in Chile and Sweden; ore textures and magnetite geochemistry. Economic Geology 89, 820-839.

Packter, A., and Doherty, W. O. S. (1989). The crystallisation of alkaline- earth metal phosphates from alkaline- metal halide and alkali metal phosphate melts: Some preliminary solubility- temperature phase diagram studies. Crystal Research and Technology 24(10), 973-977.

Pang KN, Zhou MF, Lindsley D, Zhao D, Malpas J (2008) Origin of Fe-Ti oxide ores in mafic intrusions: evidence from the Panzhihua intrusion, SW China. J Petrol 49: 295-313

Philpotts AR (1967) Origin of certain iron-titanium oxide and apatite rocks. Econ Geol 62: $303-315$

Philpotts AR (1981) A model for the generation of massif-type anorthosites. Can Mineral 19: 233-253

Philpotts AR (1982) Compositions of immiscible liquids in volcanic rocks. Contrib Miner Petrol 80: 201-218

Philpotts AR, Doyle CD (1983) Effect of magma oxidation state on the extent of silicate liquid immiscibility in a tholeiitic basalt. Am J Sci 283: 967-986

Pouchou, J.-L. and Pichoir, F. o. (1991). Quantitative Analysis of Homogeneous or Stratified

Prowatke S, Klemme S (2006) Trace element partitioning between apatite and silicate melts. Geochim Cosmochim Acta 70: 4513-4527

Qi L, Grégoire DC (2000) Determination of Trace Elements in Twenty Six Chinese Geochemistry Reference Materials by Inductively Coupled Plasma-Mass Spectrometry. Geostandards Newslett 24: 51-63

Ren R, Mu BL, Han BF, Zhang L, Chen JF, Xu Z, Song B (2009) Zircon SHRIMP $\mathrm{U}-\mathrm{Pb}$ dating of the Fanshan potassic alkaline ultramafite-syenite complex in Hebei province, China. Acta Petrol Sin 25: 588-594 (in Chinese with English abstract)

Reynolds IM (1985) Contrasted mineralogy and texture relationships in the uppermost titaniferous magnetite layers of the Bushveld Complex in the Bierkraal area north of Rustenburg. Econ Geol 80: 1027-1048

Ripley EM, Severson MJ, Hauck SA (1998) Evidence for sulfide and Fe-Ti-P-rich liquid immiscibility in the Duluth complex, Minnesota. Econ Geol 93: 1052-1062 
Roedder E (1979) Silicate liquid immiscibility in magmas. The Evolution of The Igneous Rocks Fiftieth Anniversary Perspectives, 15-59

Roedder E, Weiblen PW (1971) Petrology of silicate melt inclusions, Apollo 11 and Apollo 12 and terrestrial equivalents. Proc Lunar Planet Sci Conf 2: 507

Ryabov VV (1989) Liquation in natural glasses: the example of traps. Novosibirsk: Nauka (in Russian)

Ryerson FJ, Hess PC (1980) The role of $\mathrm{P}_{2} \mathrm{O}_{5}$ in silicate melts. Geochim Cosmochim Acta 44: 611-624

Sun J, Du W, Wang D, Li J, Xu G, Han Y (2009) Geologica characteristic and genesis of the Heishan V-Ti magnetite deposi in Damiao. Chengde Hebei Province. Acta Geol Sin 83: 1344-1363 (in Chinese with English abstract)

Tacker RC, Stormer JC (1989) A thermodynamic model for apatite solid solutions, applicable to high-temperature geologic problems. Am Miner 74: 877-888

Tegner C, Cawthorn RG, Kruger FJ (2006) Cyclicity in the Main and Upper Zones of the Bushveld Complex, South Africa: Crystallisation from a zoned magma sheet. J Petrol 47: 2257-2279

Thompson AB, Aerts M, Hack AC (2007) Liquid immiscibility in silicate melts and related systems. Rev Mineral Geochem 65: 99-127

Toplis MJ, Carroll MR (1996) Differentiation of ferro-basaltic magmas under conditions open and closed to oxygen: implication for the Skaergaard intrusion and other natural systems. J Petrol 37: 837-858

Trömmel G, Fix W, Fritze HW (1961) Arch Eisenhuttenwesen 32: 353-359

undersaturated Fe-bearing systems: An experimental setup approaching $\mathrm{fO}_{2}$ conditions of natural calc-alkaline magmas. American Mineralogist 90, 708-717.

van der Laan, S. R., and Koster van Groos, A. F. (1991). Pt-Fe alloys in experimental petrology applied to high-pressure research on Fe-bearing systems. American Mineralogist 76, 1940-1949.

Veksler IV, Dorfman AM, Borisov AA, Wirth R, Dingwell DB (2007) Liquid immiscibility and the evolution of basaltic magma. J Petrol 48: 2187-2210

Veksler IV, Dorfman AM, Danyushevsky LV, Jakobsen JK, Dingwell DB (2006) Immiscible silicate liquid partition coefficients: implications for crystal-melt element partitioning and basalt petrogenesis. Contrib Miner Petrol 152: 685-702

Watson EB (1976) Two-liquid partition coefficients: experimental data and geochemical implications. Contrib Miner Petrol 56: 119-134

Watson EB, Green TH (1981) Apatite liquid partition-coefficients for the rare-earth elements and strontium. Earth Planet Sc Lett 56: 405-421

Webster, J. D., and Piccoli, P. M. (2015). Magmatic apatite: a powerful, yet deceptive, mineral. Elements, 11(3), 177-182.

Xie GH (2005) The petrology and geochemistry of Damiao massifanorthosite and Miyun rapakivi-granite: Involving discussion on distribution and significance of global massif-anorthosite and rapakivi granite. Science Press, Beijing (in Chinese)

Yan G, Mu B (1993) Characteristics and formation temperature of the pyroxene in the Heishan anorthosite complexes near Chengde. Acta Petrol Sin 9: 300-307 (in Chinese with English abstract) 
Yang JH, Wu FY, Liu XM, Xie LW (2005) Zircon U-Pb ages and $\mathrm{H}$ isotopes and their geological significance of the Miyun rapakiv granites from Beijing. China. Acta Petrol Sin 21: 1633-1644 (in Chinese with English abstract)

Ye DH, Yang QW, Xing JR (1996) The Damiao anorthosite and vanadic-titano magnetite and apatite deposits associated with the anorthosite in Chengde, Hebei. Field Trip Guide T216, 30th International Geological Congress, Beijing, China

Yu JH, Fu HQ, Zhang FL, Wan FX (1993) The plutonism and volcanism of Proterozoic rapakivi suite near Beijing, I: Anorogenic magmatism and rifting. Beijing Geology 5: 4-20

Zhang SH, Liu SW, Zhao Y, Yang JH, Song B, Liu XM (2007) The 1.75-1.68 Ga anorthosite-mangerite-alkali granitoid-rapakivi granitic suite from the northern North China Craton: magmatism related to a Paleo-proterozoic orogen. Precambrian Research 155: 287-312

Zhao GC, Cawood PA, Wilde SA (2001) High-pressure granulites (retrograded eclogites) from the Hengshan complex, North China Craton: petrology and tectonic implications. J Petrol 42: 1141-1170

Zhao TP, Chen W, Zhou MF (2009) Geochemical and Nd-Hf isotopic constraints on the origin of the $\sim 1.74-\mathrm{Ga}$ Damiao anorthosite complex. North China Craton. Lithos 113: 673-690

Zhou MF, Robinson PT, Lesher CM, Keays RR, Zhang CJ, Malpas J (2005) Geochemistry, petrogenesis and metallogenesis of the Panzhihua gabbroic layered intrusion and associated Fe-Ti-V oxide deposits, Sichuan Province, SW China. J Petrol 46: 2253-2280 


\section{Figure captions}

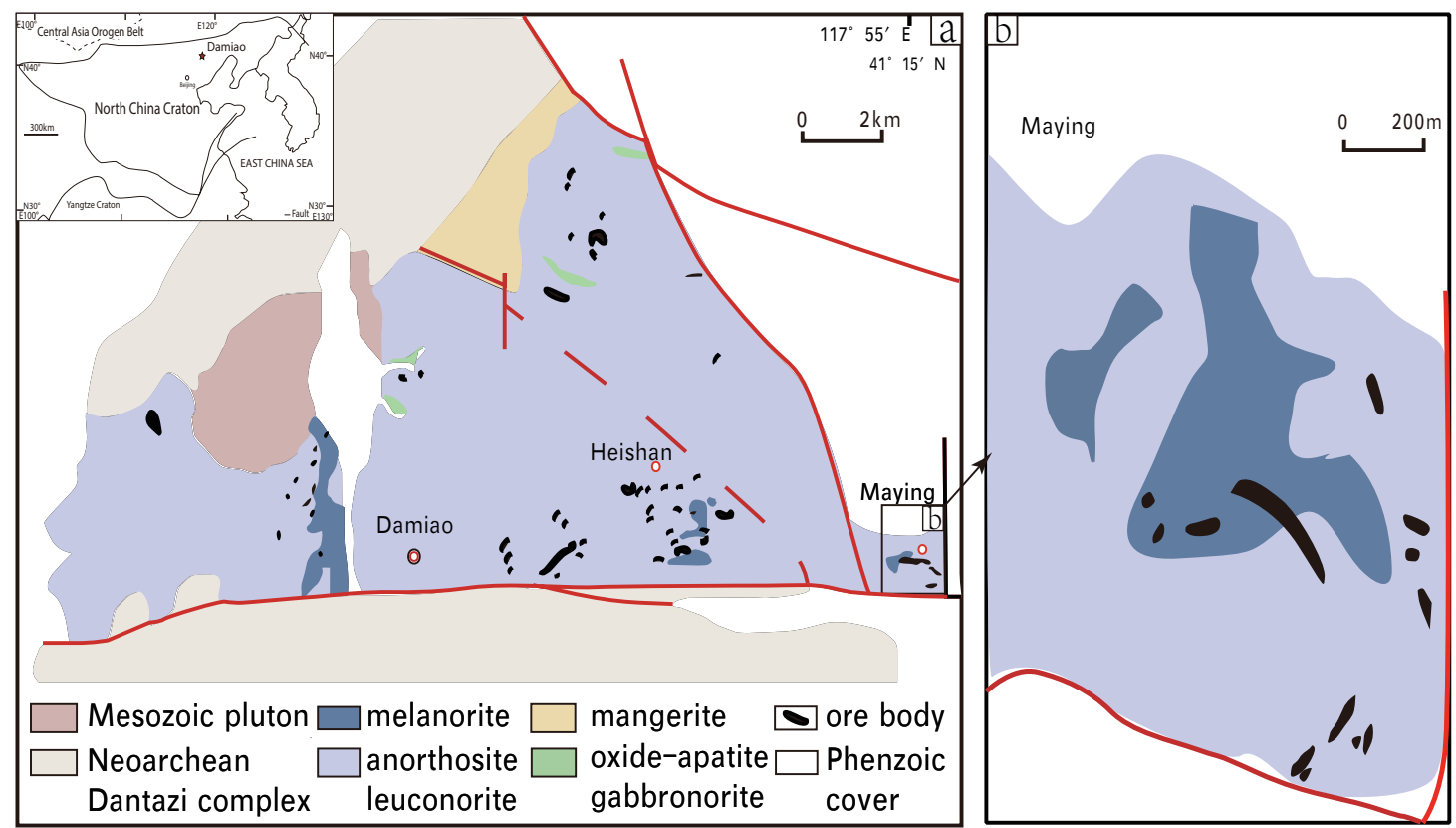

Fig. 1. a) Simplified geological map of the Damiao anorthosite complex and the hosted Fe-Ti-P ore deposit (after Ye et al., 1996; Chen et al., 2009; Ren et al., 2009). b) Schematic geological maps of the Maying district showing distributions of different ore bodies (after NGB-HGMEB 1986). 


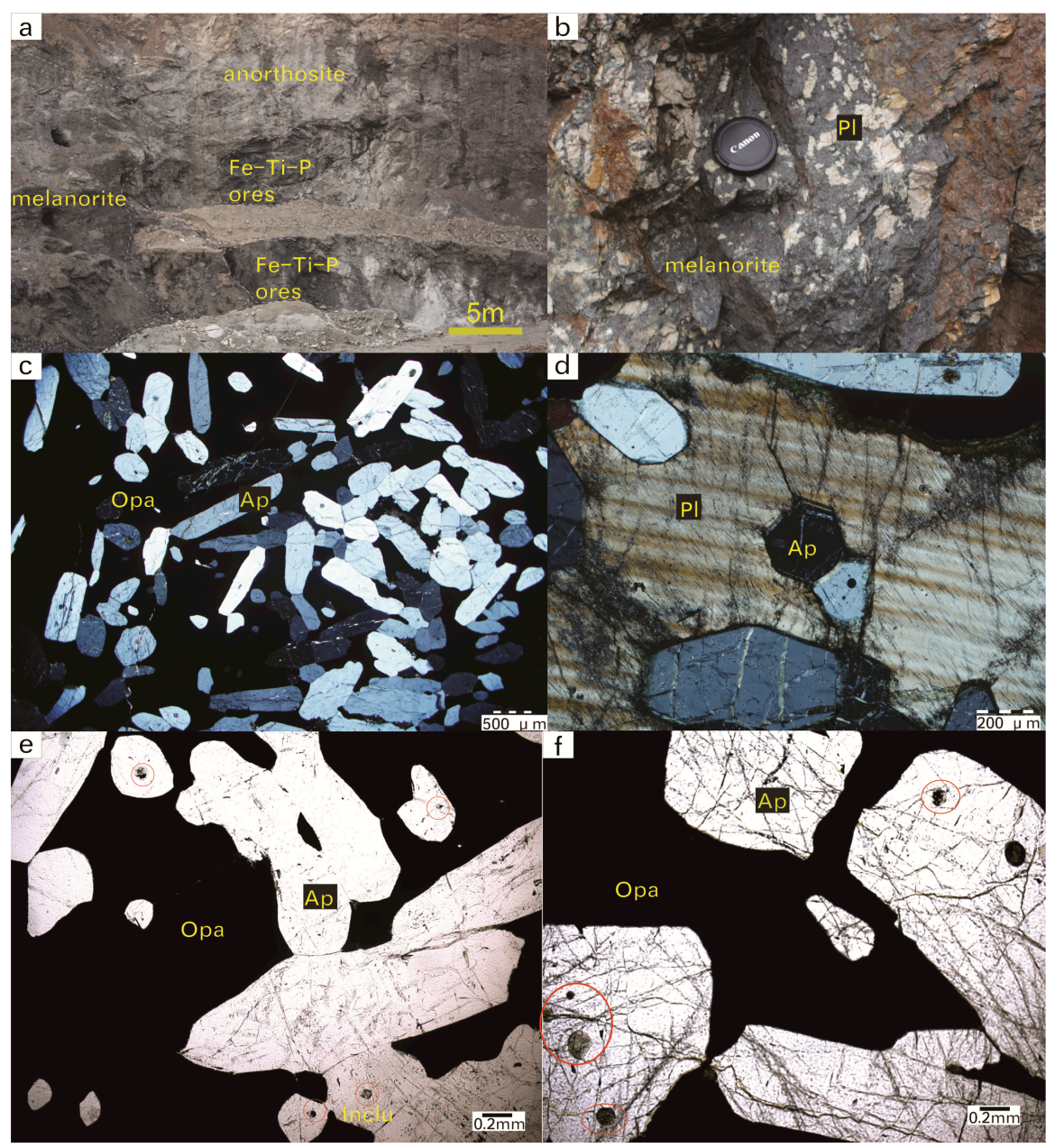

Fig. 2. a) Irregular ore bodies are enclosed by the anorthosite and melanorite. b) Plagioclase crystals in the Fe-Ti-P rich melanorite. c) Microphotographs of the nelsonite, euhedral or subhedral apatite and Fe-Ti oxide. Plane-polarized light. d) Apatites are enclosed in plagioclase. Plane-polarized light. e) and f) Abundant inclusions in the apatite in nelsonite. Plane-polarized light. Ap: apatite; Pl: plagioclase; Opa: opaque minerals; Inclu: inclusions. 

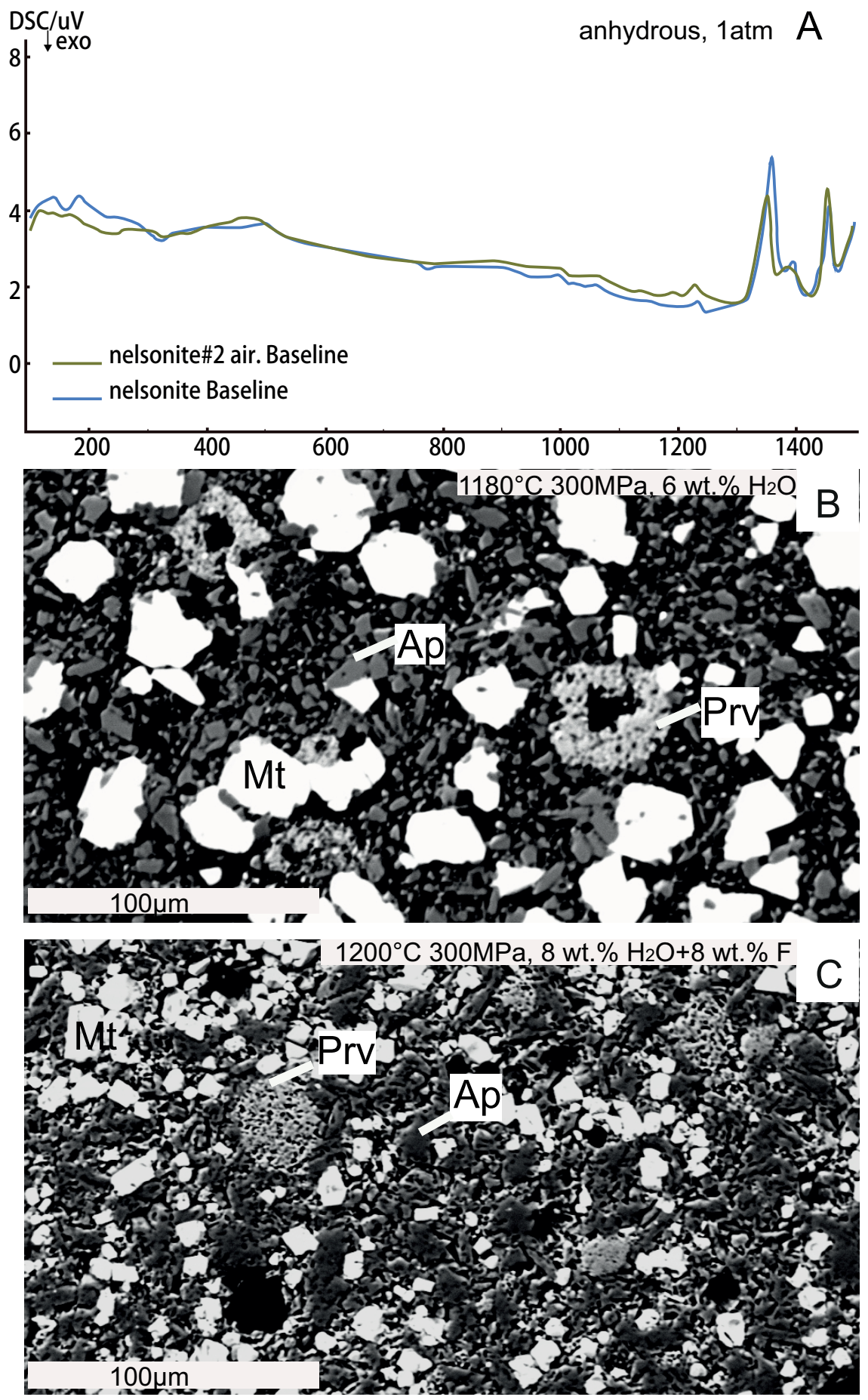

Fig. 3. (A) Calorimetric properties of the synthetic nelsonitic mixture during thermal analysis in a differential scanning calorimeter. BSE images showing the experimental product of nelsontic composition with 6 wt. $\% \mathrm{H}_{2} \mathrm{O}$ under $1180^{\circ} \mathrm{C}$ and 300MPa (B) and 8 wt. $\%+8$ wt.\% $\mathrm{F}$ under $1200{ }^{\circ} \mathrm{C}$ and $300 \mathrm{MPa}(\mathrm{C})$. 


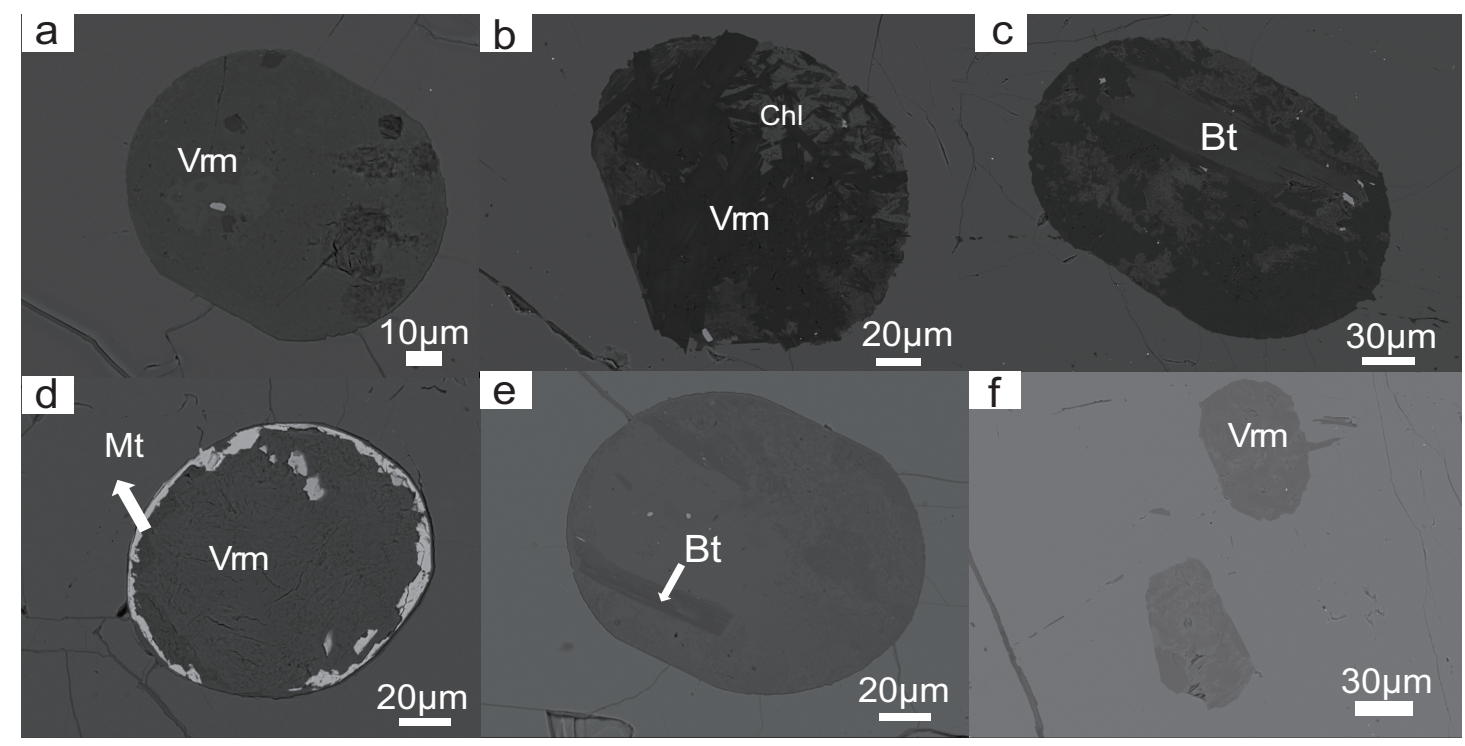

Fig. 4. Backscattered electron (BSE) images (a-f) of apatite-host melt inclusions in the Damiao anorthosite complex.
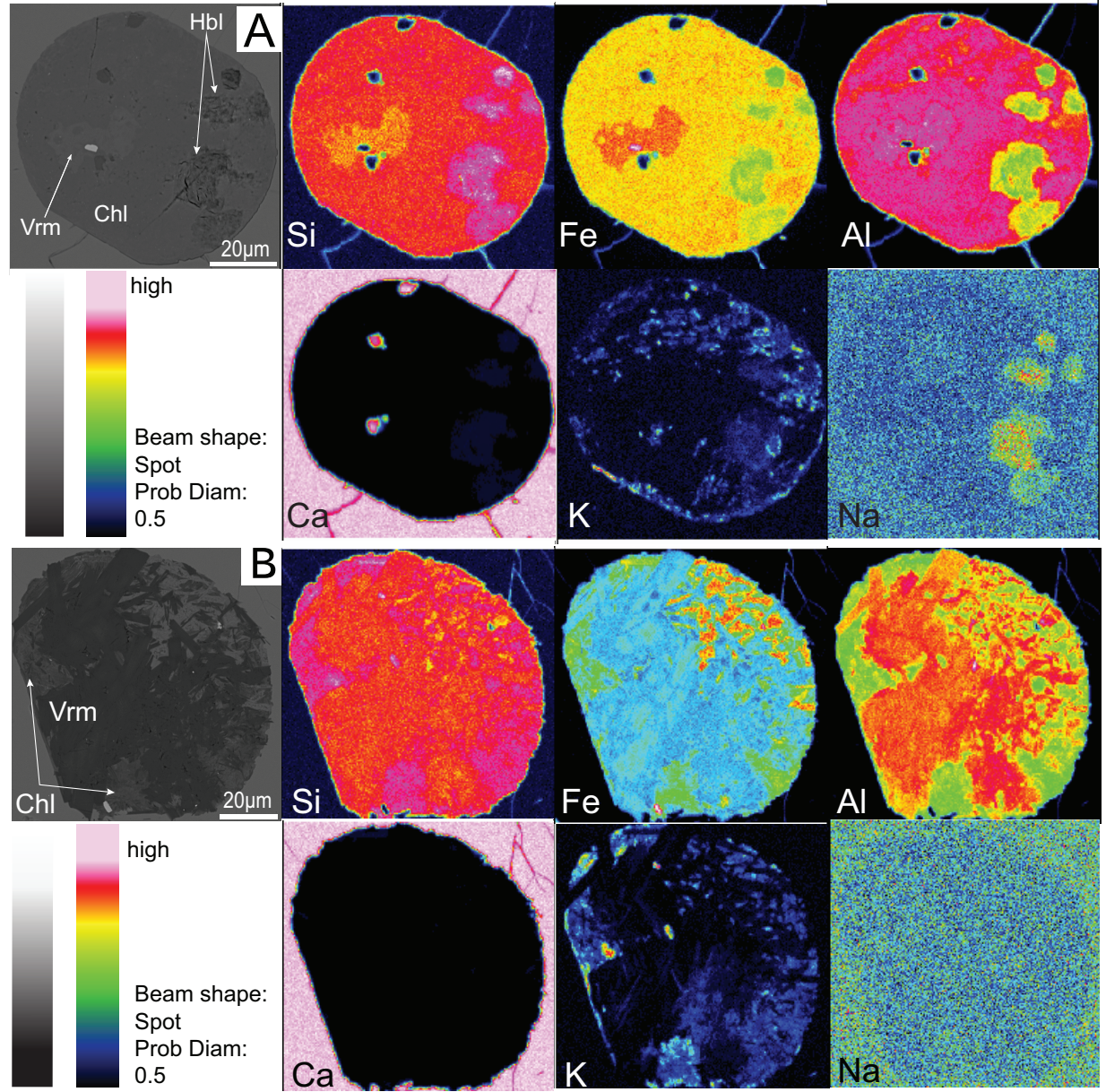

Fig. 5. BSE image and element maps of two representative inclusions (Sample My-4-2 and My-4-3) showing that the daughter minerals in the inclusions have almost homogeneous compositions. Graphic symbols $h$ ) indicate the variation of the chemical composition. Abbreviation: Vrm, vermiculite; Chl, chlorite; Hbl, 
hornblende.
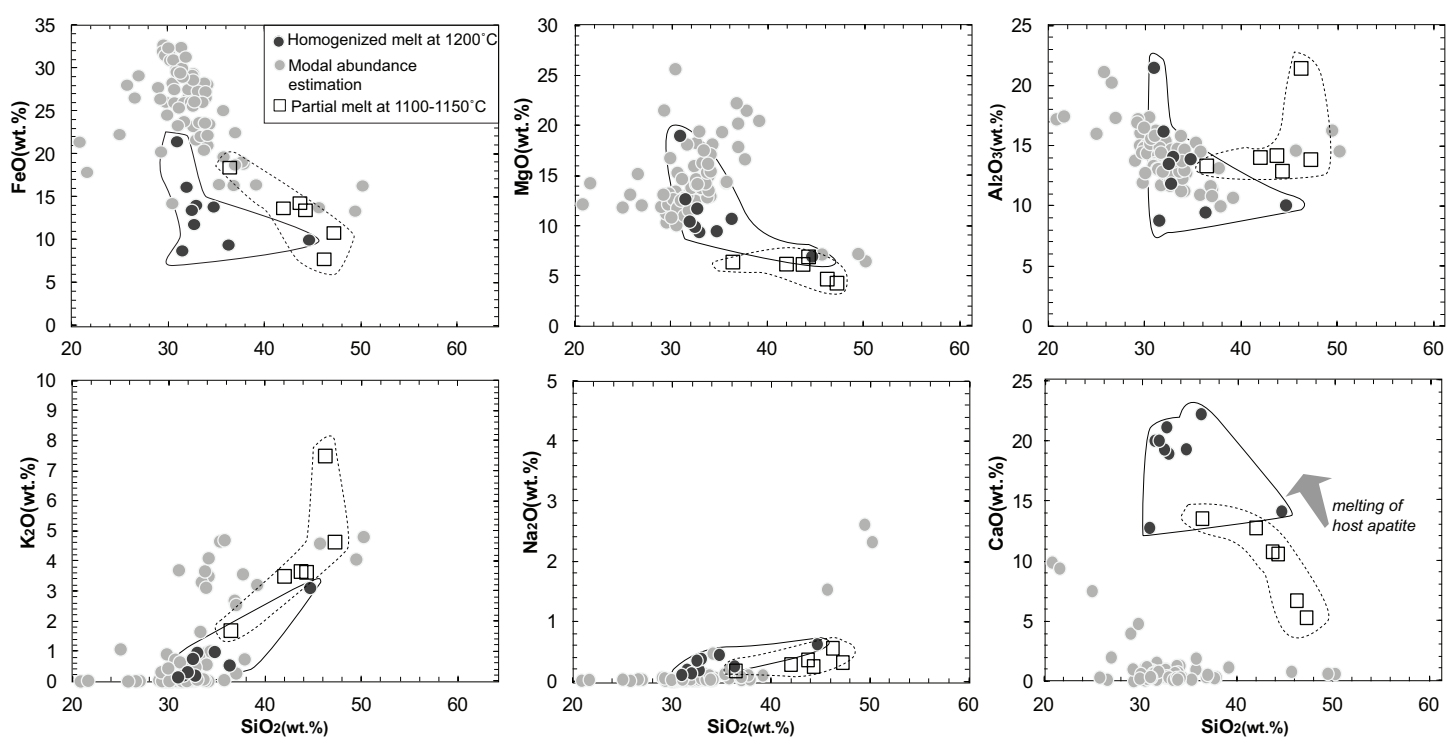

Fig. 6. Variation diagram for the average composition of melt inclusions which are estimated by modal abundance and obtained by homogenization. 


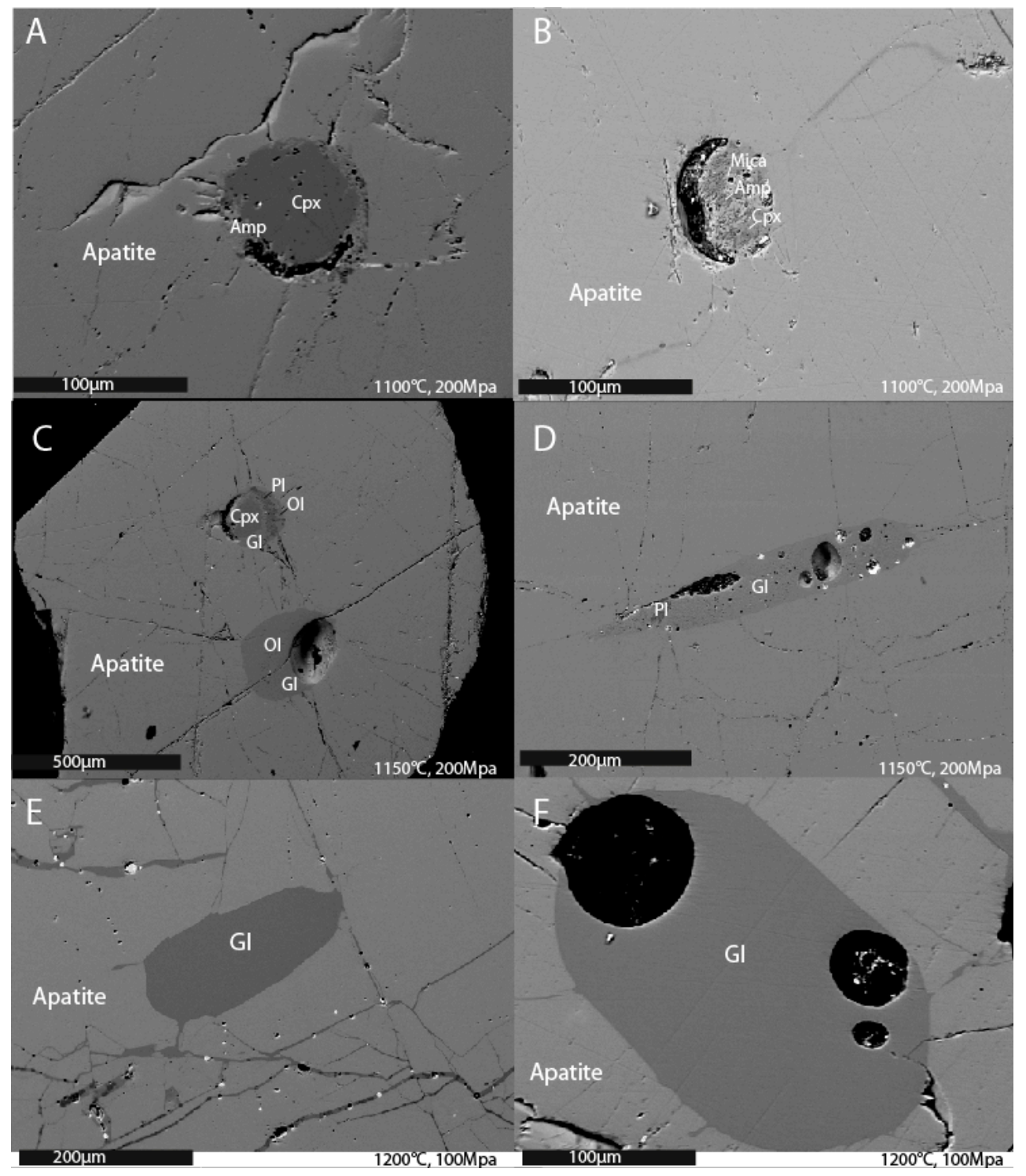

Fig. 7. Backscattered electron (BSE) images (a-f) showing the apatite-host melt inclusions after re-homogenization in the Damiao anorthosite complex. See text for details. 


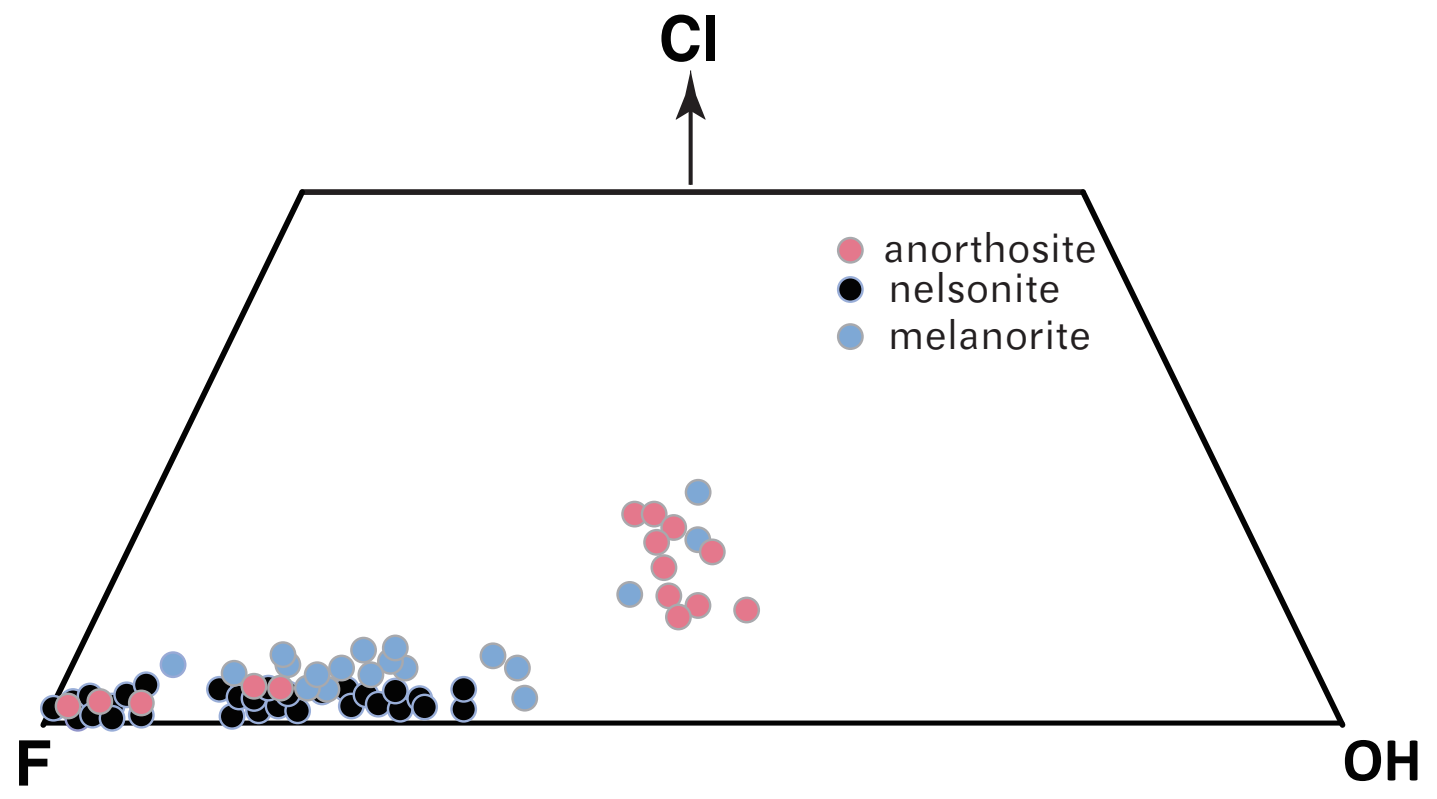

Fig. 8. Plots of F-Cl-OH variability in the halogen-site in apatite.
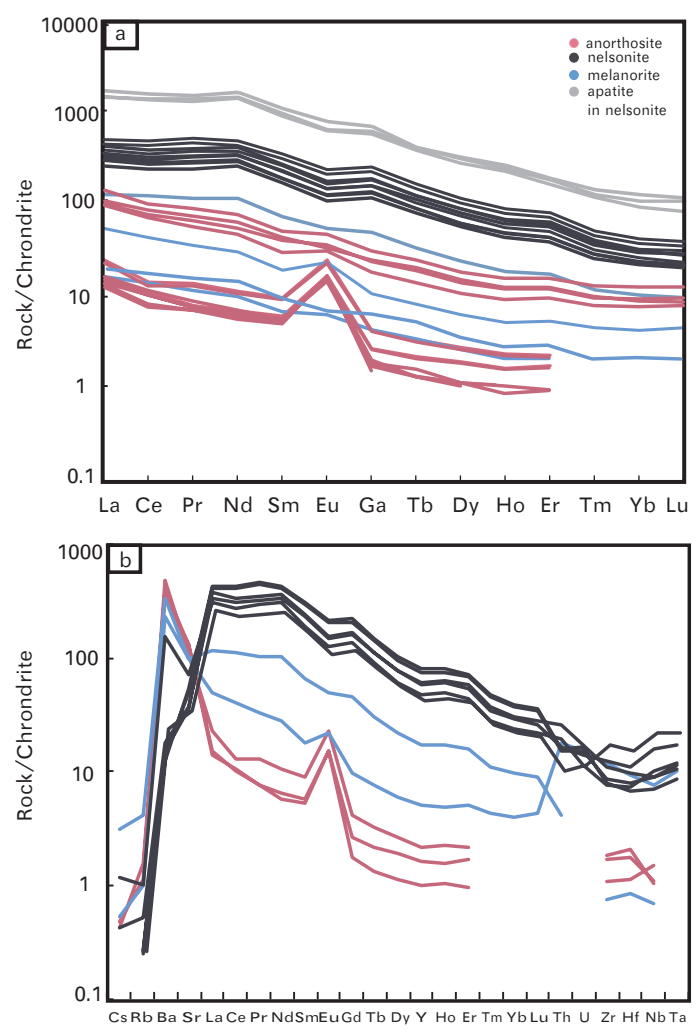

Fig. 9. a) Chondrite-normalized plots of REE in nelsonite. b) Trace elemental patterns of nelsonite. Chondrite values are after McDonough and Sun (1995), REE concentrations of apatite samples are from Chen et al., 2013. 

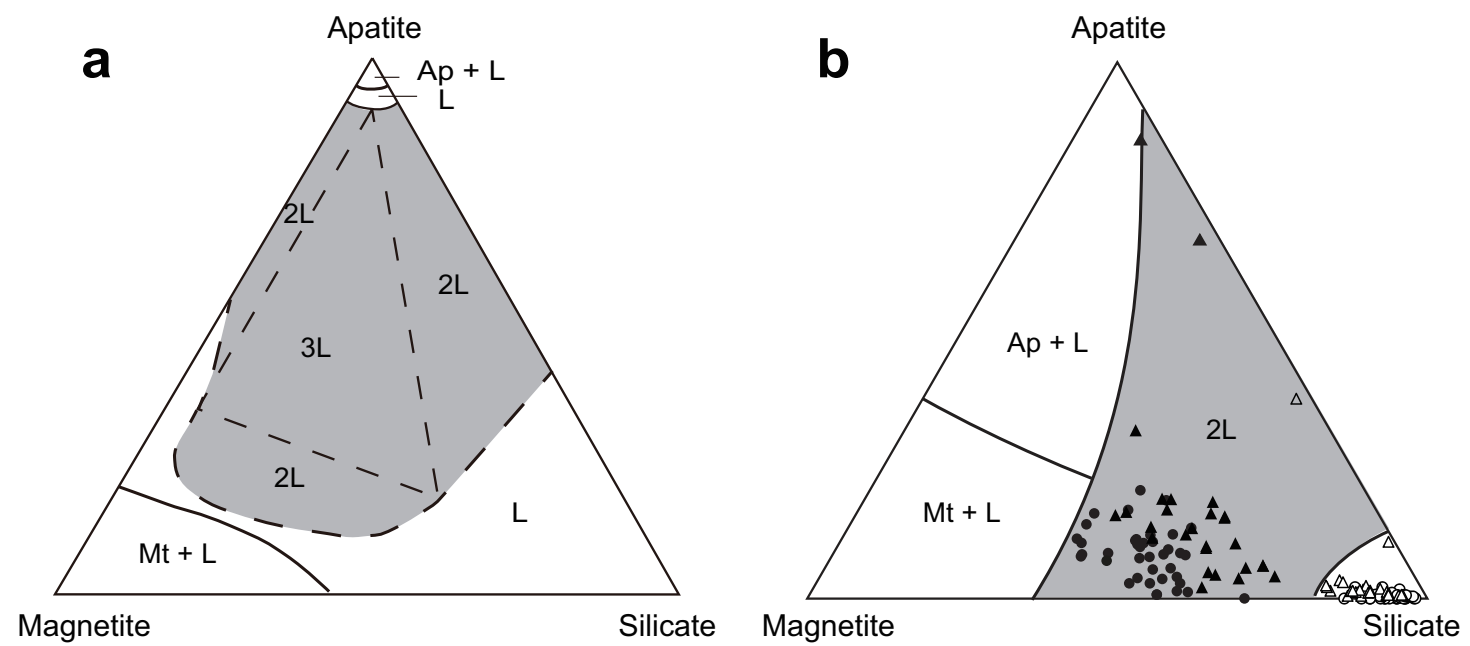

Fig. 10. Schematic pseudoternary phase diagram of the system magnetite-apatite-diorite. a) modified from Philpotts, 1967. b) plots of immiscible melts, experimental data are from Philpotts, 1981; Philpotts and Doyle, 1983; Bogaerts and Schmidt, 2006; Charlier and Grove, 2012; natural lava data are from Roedder and Weiblen, 1971; Philpotts, 1982; Hageskov and Pedersen, 1986; Ryabov, 1989; Charlier et al., 2013.
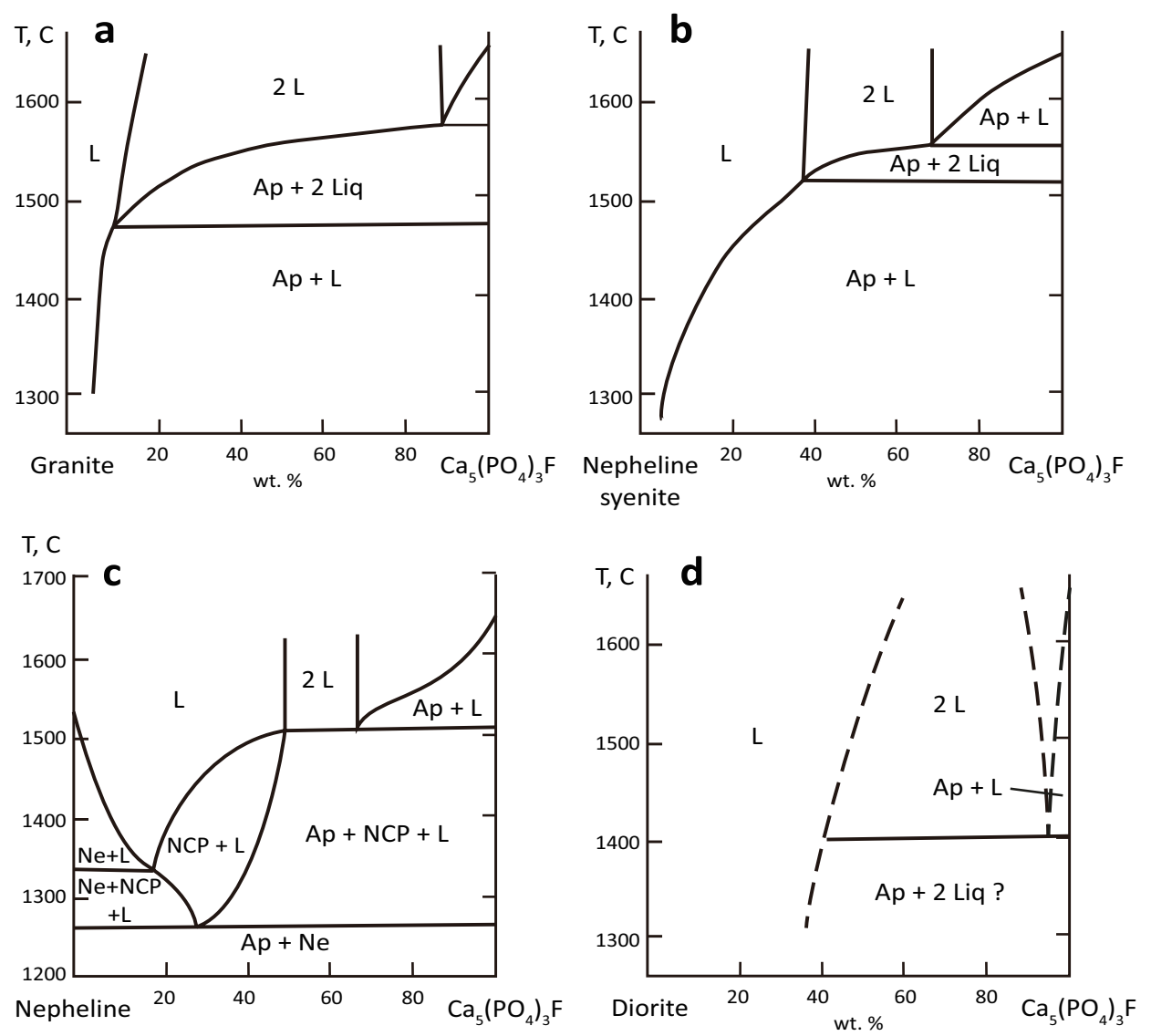

Fig. 11. Phase diagrams of the pseudobinary granite-apatite section, nepheline syenite-apatite section, nepheline-apatite section and diorite-apatite section (Modified from Kogarko, 1971; Krigman and Krot. 1992). Abbreviation: Ap=Apatite; $\mathrm{Ne}=$ Nepheline; $\mathrm{NCP}=\mathrm{NaCaPO}_{4}$. 

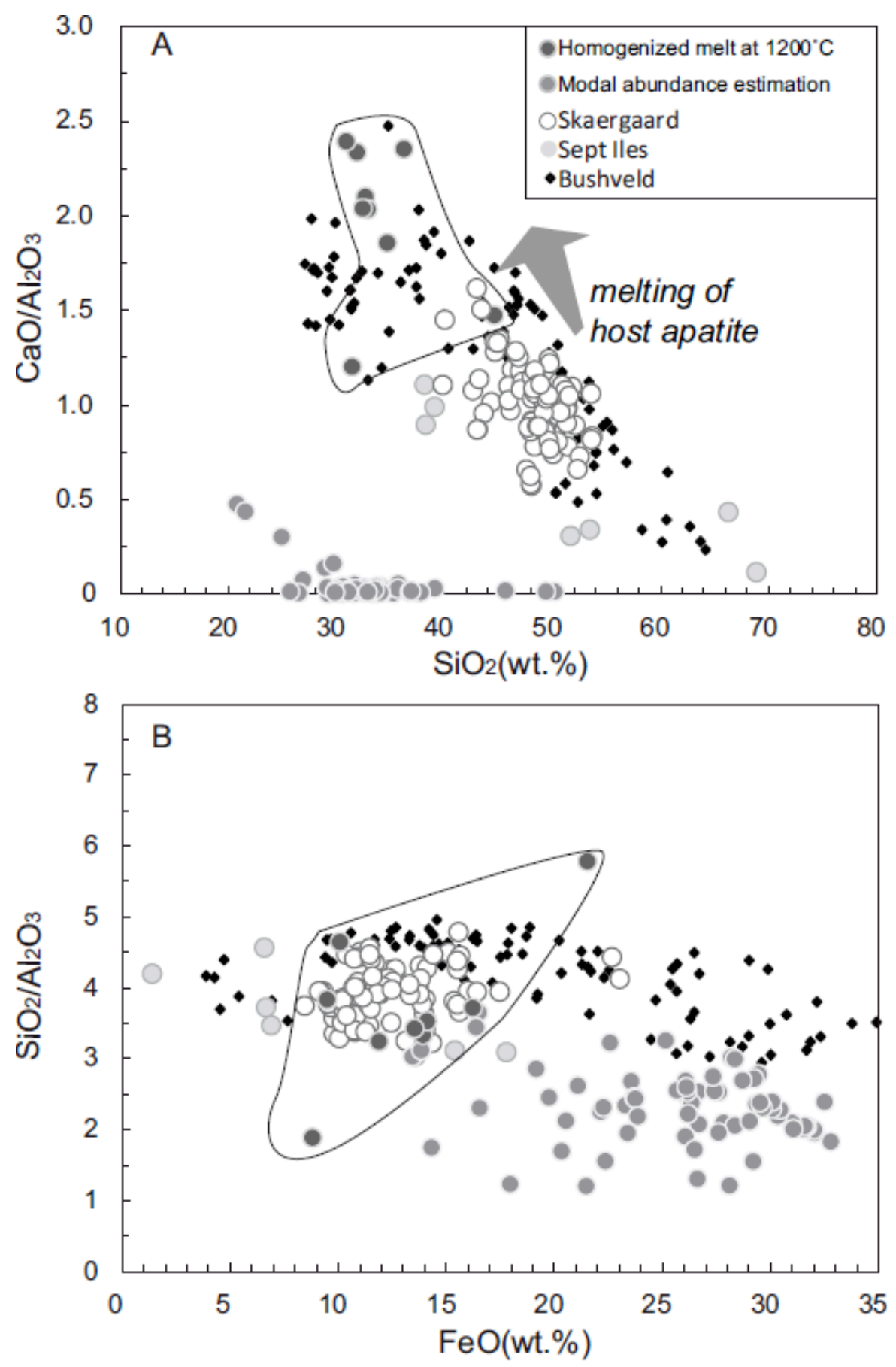

Fig. 12. a) Variation diagram for the bulk compositions of the melt inclusions. The composition of the inclusions hosted in apatite from Skaergaard (Jakobsen et al., 2011), Sept Iles (Namur et al., 2012) and Bushveld (Fischer et al., 2016) are plotted for comparison. 


\section{Table captions}

Table 1. Starting composition for experiments.

\begin{tabular}{cccccccccccccc}
\hline & $\mathrm{SiO}_{2}$ & $\mathrm{TiO}_{2}$ & $\mathrm{Al}_{2} \mathrm{O}_{3}$ & $\mathrm{FeOt}$ & $\mathrm{MnO}$ & $\mathrm{MgO}$ & $\mathrm{CaO}$ & $\mathrm{Na}_{2} \mathrm{O}$ & $\mathrm{K}_{2} \mathrm{O}$ & $\mathrm{P}_{2} \mathrm{O}_{5}$ & $\mathrm{~F}$ & $\mathrm{H}_{2} \mathrm{O}$ & Total \\
\hline $\mathbf{M - 1}$ & 0.02 & 8.78 & 4.02 & 52.35 & 0.13 & 1.08 & 18.64 & 0.01 & 0.01 & 14.26 & & & 100 \\
$\mathbf{M - 2}$ & 0.02 & 8.25 & 3.78 & 49.21 & 0.12 & 1.02 & 17.52 & 0.01 & 0.01 & 13.40 & & 6 & 100 \\
$\mathbf{M - 3}$ & 0.02 & 7.38 & 3.38 & 43.97 & 0.11 & 0.91 & 15.66 & 0.01 & 0.01 & 11.98 & 8 & 8 & 100 \\
\hline
\end{tabular}

Table 2. Experimental conditions, phase assemblages and mineral composition analyzed by EMPA.

\begin{tabular}{|c|c|c|c|c|c|c|}
\hline Sample & \multicolumn{3}{|c|}{ M-2 } & \multicolumn{3}{|c|}{ M-3 } \\
\hline $\mathrm{T}\left[{ }^{\circ} \mathrm{C}\right]$ & \multicolumn{3}{|c|}{1180} & \multicolumn{3}{|c|}{1200} \\
\hline $\mathrm{P}[\mathrm{MPa}]$ & \multicolumn{3}{|c|}{300} & \multicolumn{3}{|c|}{300} \\
\hline$f \mathrm{O}_{2}$ & \multicolumn{3}{|c|}{$\mathrm{FMQ}+3.3$} & \multicolumn{3}{|c|}{$\mathrm{FMQ}+3.3$} \\
\hline $\mathrm{aH}_{2} \mathrm{O}$ & \multicolumn{3}{|c|}{1} & \multicolumn{3}{|c|}{1} \\
\hline Phases & $\begin{array}{c}\text { Magnetite } \\
(\mathrm{n}=10)\end{array}$ & $\begin{array}{l}\text { Apatite } \\
(\mathrm{n}=8)\end{array}$ & $\begin{array}{c}\text { Perovskite } \\
\quad(n=10)\end{array}$ & $\begin{array}{l}\text { Magnetite } \\
(\mathrm{n}=10)\end{array}$ & $\begin{array}{l}\text { Apatite } \\
(n=10)\end{array}$ & $\begin{array}{c}\text { Perovskite } \\
(\mathrm{n}=9)\end{array}$ \\
\hline $\mathrm{SiO}_{2}$ & 0.08 & 0.10 & 0.05 & 0 & 0.07 & 0.00 \\
\hline $\mathrm{TiO}_{2}$ & 0.33 & 0.26 & 53.50 & 0.53 & 0.13 & 51.61 \\
\hline $\mathrm{Al}_{2} \mathrm{O}_{3}$ & 4.14 & 0.17 & 0.70 & 5.81 & 0.00 & 0.47 \\
\hline $\mathrm{FeO}$ & 85.93 & 0.94 & 3.32 & 84.71 & 0.76 & 3.28 \\
\hline $\mathrm{MnO}$ & 0.38 & 0.03 & 0.10 & 0.34 & 0.04 & 0.03 \\
\hline $\mathrm{MgO}$ & 0.59 & -0.07 & -0.09 & 0.41 & 0 & 0 \\
\hline $\mathrm{CaO}$ & 2.16 & 54.42 & 40.21 & 2.14 & 56.37 & 42.43 \\
\hline $\mathrm{Na}_{2} \mathrm{O}$ & 0.03 & 0.02 & 0.08 & 0.01 & 0.01 & 0.27 \\
\hline $\mathrm{K}_{2} \mathrm{O}$ & -0.01 & 0.00 & 0.02 & 0.01 & 0.00 & 0.04 \\
\hline $\mathrm{P}_{2} \mathrm{O}_{5}$ & 0.08 & 42.33 & 0.06 & 0.20 & 43.01 & 0.15 \\
\hline $\mathrm{F}_{2} \mathrm{O}_{-1}$ & & & & 0.73 & 5.07 & 2.66 \\
\hline Total & 93.71 & 98.20 & 97.95 & 94.86 & 105.47 & 100.87 \\
\hline
\end{tabular}

$\mathrm{N}$ represents the number of analysis spots. 
Table. 3. Representative average compositions (wt. \%) of melt inclusions in apatite by modal abundance estimation.

\begin{tabular}{cccccccccccccc}
\hline No. & $8-1$ & $8-2$ & $8-4$ & $8-5$ & $8-6$ & $8-7$ & $4-1$ & $4-2$ & $4-3$ & $4-6$ & $4-7$ & $15-20$ & $4-9$ \\
\hline $\mathrm{SiO}_{2}$ & 29.95 & 29.49 & 29.44 & 26.91 & 28.93 & 39.11 & 35.73 & 30.44 & 30.41 & 35.25 & 26.51 & 32.55 & 24.93 \\
$\mathrm{TiO}_{2}$ & 0.01 & 0.01 & 0.02 & 0.31 & 0.02 & 0.46 & 0.33 & 0.11 & 0.04 & 1.04 & 0.07 & 0.37 & 0.22 \\
$\mathrm{Al}_{2} \mathrm{O}_{3}$ & 14.89 & 16.10 & 15.06 & 17.35 & 13.80 & 10.71 & 14.55 & 14.79 & 17.41 & 15.29 & 20.29 & 12.74 & 16.03 \\
$\mathrm{FeOt}$ & 31.85 & 32.78 & 32.03 & 29.20 & 27.82 & 16.49 & 19.75 & 28.35 & 14.32 & 16.54 & 26.61 & 25.66 & 22.36 \\
$\mathrm{MnO}$ & 0.16 & 0.26 & 0.16 & 0.28 & 0.32 & 0.09 & 0.14 & 0.13 & 0.04 & 0.07 & 0.10 & 0.16 & 0.41 \\
$\mathrm{MgO}$ & 11.91 & 10.39 & 11.30 & 12.09 & 11.95 & 20.53 & 14.44 & 13.47 & 25.69 & 19.41 & 15.23 & 14.70 & 11.88 \\
$\mathrm{CaO}$ & 0.35 & 0.45 & 0.34 & 2.01 & 3.99 & 1.18 & 1.92 & 1.16 & 0.11 & 0.17 & 0.16 & 0.98 & 7.53 \\
$\mathrm{Na} 2 \mathrm{O}$ & 0.02 & 0.03 & 0.03 & 0.03 & 0.06 & 0.10 & 0.20 & 0.03 & 0.01 & 0.13 & 0.04 & 0.05 & 0.03 \\
$\mathrm{~K} 2 \mathrm{O}$ & 0.01 & 0.01 & 0.01 & 0.02 & 0.04 & 3.21 & 4.70 & 0.08 & 0.11 & 4.66 & 0.01 & 0.65 & 1.07 \\
$\mathrm{~F}$ & 0.00 & 0.00 & 0.00 & 0.00 & 0.00 & 0.86 & 0.60 & 0.00 & 0.33 & 1.19 & 0.00 & 0.04 & 0.06 \\
$\mathrm{Cl}$ & 0.00 & 0.00 & 0.00 & 0.04 & 0.00 & 0.03 & 0.39 & 0.05 & 0.07 & 0.07 & 0.05 & 0.14 & 0.04 \\
$\mathrm{P}_{2} \mathrm{O}_{5}$ & & & & & & & & & & & & & 8 \\
$\mathrm{Total}$ & 89.15 & 89.51 & 88.37 & 88.24 & 86.96 & 92.77 & 92.75 & 88.60 & 88.54 & 93.81 & 89.06 & 88.04 & 84.56 \\
\hline
\end{tabular}

continued.

\begin{tabular}{ccccccccc}
\hline No. & $12-7$ & $12-8$ & $15-25$ & $4-5$ & $4-10$ & $12-2$ & $6-10$ & $15-26$ \\
\hline $\mathrm{SiO}_{2}$ & 49.39 & 45.63 & 32.7 & 50.16 & 20.79 & 37.63 & 30.19 & 29.16 \\
$\mathrm{TiO}_{2}$ & 0.10 & 0.11 & 0.08 & 0.08 & 0.02 & 0.67 & 0.04 & 0.48 \\
$\mathrm{Al}_{2} \mathrm{O}_{3}$ & 16.30 & 14.63 & 14.71 & 14.57 & 17.24 & 13.17 & 14.42 & 16.97 \\
$\mathrm{FeOt}$ & 13.44 & 13.84 & 26.17 & 16.37 & 21.47 & 19.16 & 30.99 & 26.48 \\
$\mathrm{MnO}$ & 0.06 & 0.07 & 0.15 & 0.09 & 0.60 & 0.10 & 0.16 & 0.20 \\
$\mathrm{MgO}$ & 7.24 & 7.19 & 14.22 & 6.51 & 12.20 & 16.69 & 12.71 & 13.16 \\
$\mathrm{CaO}$ & 0.65 & 0.82 & 0.44 & 0.64 & 9.90 & 0.29 & 0.48 & 1.02 \\
$\mathrm{Na} 2 \mathrm{O}$ & 2.61 & 1.53 & 0.03 & 2.32 & 0.02 & 0.11 & 0.03 & 0.06 \\
$\mathrm{~K}_{2} \mathrm{O}$ & 4.06 & 4.59 & 0.48 & 4.81 & 0.01 & 3.57 & 0.01 & 0.31 \\
$\mathrm{~F}$ & 0.00 & 0.00 & 0.09 & 0.00 & 0.00 & 0.60 & 0.00 & 0.07 \\
$\mathrm{Cl}$ & 0.02 & 0.01 & 0.07 & 0.01 & 0.04 & 0.02 & 0.00 & 0.04 \\
$\mathrm{P}_{2} \mathrm{O}_{5}$ & & & & & & & & \\
$\mathrm{Total}$ & 93.89 & 88.42 & 89.15 & 95.57 & 82.27 & 92.00 & 89.03 & 87.95 \\
\hline
\end{tabular}


Table 4. Chemical compositions of the phases in the re-homogenized inclusions hosted in apatite, from the Damiao complex.

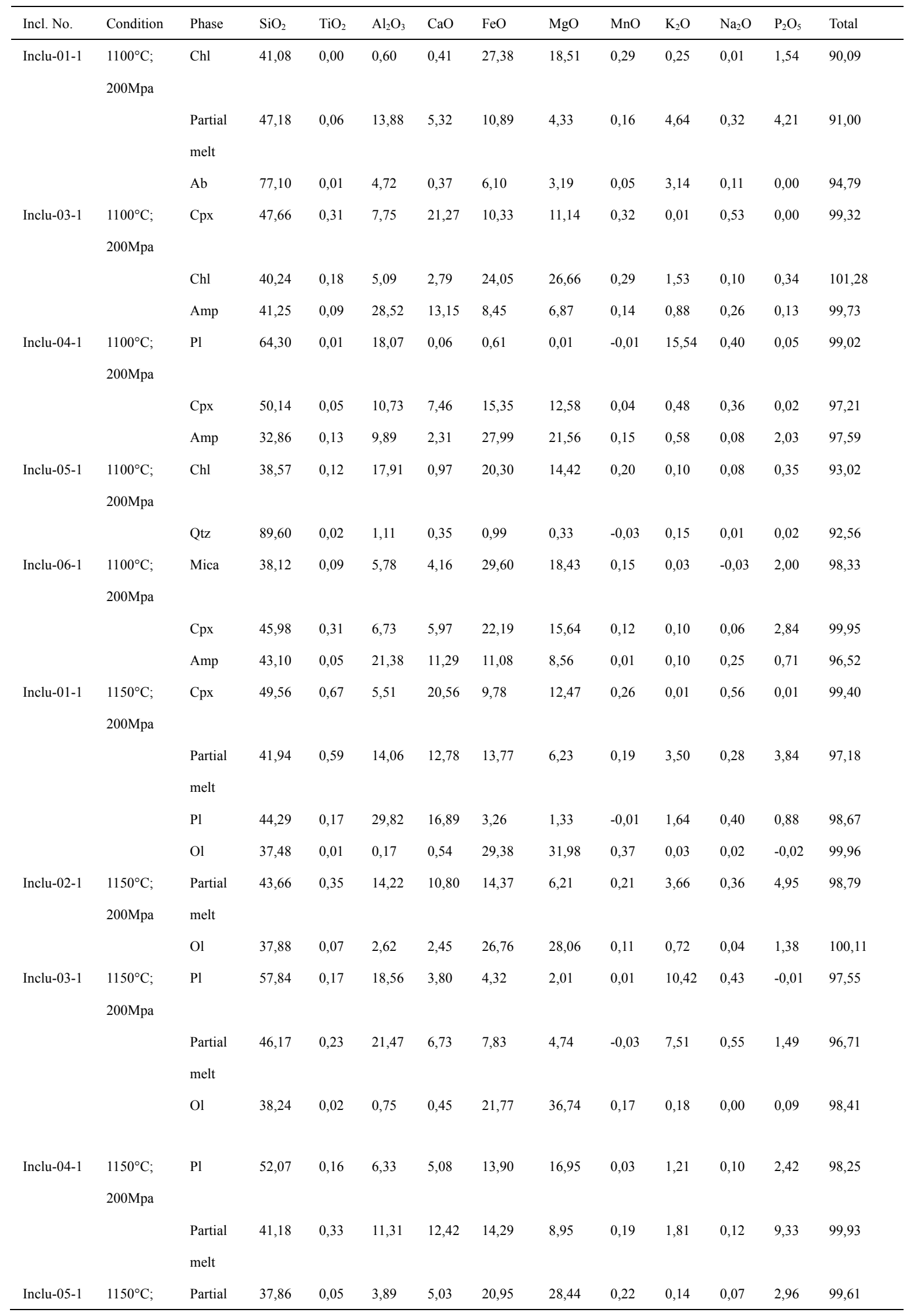




\begin{tabular}{|c|c|c|c|c|c|c|c|c|c|c|c|c|c|}
\hline & $200 \mathrm{Mpa}$ & melt & & & & & & & & & & & \\
\hline & & An & 43,73 & 0,00 & 33,54 & 18,14 & 1,18 & 0,76 & 0,10 & 0,25 & 0,37 & 0,59 & 98,67 \\
\hline \multirow[t]{3}{*}{ Inclu-06-1 } & $1150^{\circ} \mathrm{C}$ & Partial & 36,37 & 0,03 & 13,36 & 13,56 & 18,50 & 6,44 & 0,12 & 1,70 & 0,18 & 8,45 & 98,69 \\
\hline & $200 \mathrm{Mpa}$ & melt & & & & & & & & & & & \\
\hline & & An & 44,67 & 0,00 & 34,40 & 17,70 & 1,38 & 0,72 & 0,04 & 0,53 & 0,27 & 0,26 & 99,95 \\
\hline \multirow[t]{3}{*}{ Inclu-07 } & $1150^{\circ} \mathrm{C}$ & Partial & 44,23 & 0,06 & 12,92 & 10,61 & 13,54 & 6,96 & 0,11 & 3,64 & 0,25 & 6,59 & 98,91 \\
\hline & $200 \mathrm{Mpa}$ & melt & & & & & & & & & & & \\
\hline & & Kfs & 68,87 & 0,00 & 16,70 & 0,19 & 0,45 & 0,09 & 0,10 & 13,88 & 0,20 & 0,03 & 100,52 \\
\hline \multirow[t]{2}{*}{ Inclu-01 } & $1200^{\circ} \mathrm{C}$ & Melt & 34,70 & 0,03 & 10,41 & 19,32 & 13,92 & 9,52 & 0,24 & 0,99 & 0,45 & 8,83 & 98,40 \\
\hline & $100 \mathrm{Mpa}$ & & & & & & & & & & & & \\
\hline \multirow[t]{2}{*}{ Inclu-02 } & $1200^{\circ} \mathrm{C}$ & Melt & 31,44 & 0,11 & 16,67 & 20,03 & 8,81 & 12,71 & 0,25 & 0,20 & 0,20 & 7,11 & 97,53 \\
\hline & $100 \mathrm{Mpa}$ & & & & & & & & & & & & \\
\hline \multirow[t]{2}{*}{ Inclu-03 } & $1200^{\circ} \mathrm{C}$ & Melt & 32,67 & 0,12 & 10,07 & 21,16 & 11,88 & 11,77 & 0,32 & 0,20 & 0,19 & 9,22 & 97,61 \\
\hline & $100 \mathrm{Mpa}$ & & & & & & & & & & & & \\
\hline \multirow[t]{2}{*}{ Inclu-04 } & $1200^{\circ} \mathrm{C}$ & Melt & 32,88 & 0,28 & 9,32 & 18,96 & 14,11 & 9,43 & 0,15 & 0,96 & 0,38 & 11,77 & 98,23 \\
\hline & $100 \mathrm{Mpa}$ & & & & & & & & & & & & \\
\hline \multirow[t]{2}{*}{ Inclu-05 } & $1200^{\circ} \mathrm{C}$ & Melt & 32,43 & 0,17 & 9,47 & 19,31 & 13,53 & 9,95 & 0,19 & 0,75 & 0,35 & 11,90 & 98,05 \\
\hline & $100 \mathrm{Mpa}$ & & & & & & & & & & & & \\
\hline \multirow[t]{2}{*}{ Inclu-06 } & $1200^{\circ} \mathrm{C}$ & Melt & 44,60 & 0,04 & 9,60 & 14,15 & 10,08 & 6,99 & 0,20 & 3,12 & 0,62 & 7,17 & 96,57 \\
\hline & $100 \mathrm{Mpa}$ & & & & & & & & & & & & \\
\hline \multirow[t]{2}{*}{ Inclu-07 } & $1200^{\circ} \mathrm{C}$ & Melt & 36,25 & 0,10 & 9,45 & 22,24 & 9,49 & 10,75 & 0,28 & 0,54 & 0,25 & 8,70 & 98,05 \\
\hline & $100 \mathrm{Mpa}$ & & & & & & & & & & & & \\
\hline \multirow[t]{2}{*}{ Inclu-08 } & $1200^{\circ} \mathrm{C}$ & Melt & 31,89 & 0,05 & 8,58 & 20,04 & 16,22 & 10,48 & 0,21 & 0,31 & 0,14 & 10,41 & 98,33 \\
\hline & 100Mpa & & & & & & & & & & & & \\
\hline \multirow[t]{2}{*}{ Inclu-09 } & $1200^{\circ} \mathrm{C}$ & Melt & 30,90 & 0,13 & 5,34 & 12,79 & 21,52 & 19,03 & 0,21 & 0,14 & 0,11 & 8,60 & 98,78 \\
\hline & $100 \mathrm{Mpa}$ & & & & & & & & & & & & \\
\hline
\end{tabular}

Abbreviation: $\mathrm{Chl}=$ chlorite; $\mathrm{Ab}=$ albite; $\mathrm{Cpx}=$ clinopyroxene; $\mathrm{Amp}=$ amphibole; $\mathrm{Pl}=$ plagioclase; $\mathrm{Qtz}=$ quartz; $\mathrm{Ol}=$ olivine; $\mathrm{Kfs}=\mathrm{K}=$ feldspar. Note: partial melt is the melt co-exists with the mineral phases after the re-homogenization, whereas melt means the inclusions are entirely molten after the heating.

Table. 5. Representative chemical compositions (wt. \%) of apatite.

\begin{tabular}{|c|c|c|c|c|c|c|c|c|c|c|}
\hline & $8-1$ & $8-2$ & $4-4$ & $4-5$ & $6-1$ & $2-1$ & $2-2$ & $18-2$ & $19-1$ & $21-5$ \\
\hline \multicolumn{7}{|c|}{ nelsonite } & \multicolumn{2}{|c|}{ anorthosite } & \multicolumn{2}{|c|}{ melanorite } \\
\hline $\mathrm{P}_{2} \mathrm{O}_{5}$ & 42.36 & 42.82 & 42.71 & 42.24 & 42.73 & 42.34 & 42.44 & 42.59 & 43.02 & 42.22 \\
\hline $\mathrm{SiO}_{2}$ & 0.05 & 0.07 & 0.06 & 0.06 & 0.07 & 0.13 & 0.27 & 0.13 & 0.04 & 0.16 \\
\hline $\mathrm{FeO}$ & 0.08 & 0.11 & 0.20 & 0.18 & 0.31 & 0.20 & 0.12 & 0.11 & 0.05 & 0.28 \\
\hline $\mathrm{MnO}$ & 0.02 & 0.04 & 0.06 & 0.07 & 0.04 & 0.01 & 0.03 & 0.00 & 0.01 & 0.03 \\
\hline $\mathrm{CaO}$ & 54.25 & 54.38 & 54.44 & 54.02 & 53.68 & 53.68 & 53.83 & 54.48 & 54.76 & 53.79 \\
\hline $\mathrm{Na}_{2} \mathrm{O}$ & 0.00 & 0.01 & 0.00 & 0.00 & 0.00 & 0.00 & 0.00 & 0.01 & 0.00 & 0.00 \\
\hline $\mathrm{F}$ & 3.91 & 3.80 & 3.80 & 3.48 & 3.59 & 1.71 & 2.03 & 2.87 & 3.31 & 1.57 \\
\hline $\mathrm{Cl}$ & 0.08 & 0.08 & 0.09 & 0.10 & 0.09 & 0.76 & 0.39 & 0.21 & 0.06 & 0.50 \\
\hline
\end{tabular}




\begin{tabular}{ccccccccccc}
\hline $\mathrm{SO}_{3}$ & 0.01 & 0.00 & 0.01 & 0.00 & 0.00 & 0.00 & 0.01 & 0.00 & 0.01 & 0.00 \\
$\mathrm{Y}_{2} \mathrm{O}_{3}$ & 0.01 & 0.00 & 0.01 & 0.02 & 0.00 & 0.02 & 0.02 & 0.00 & 0.00 & 0.04 \\
$\mathrm{La}_{2} \mathrm{O}_{3}$ & 0.07 & 0.00 & 0.07 & 0.06 & 0.08 & 0.01 & 0.00 & 0.04 & 0.00 & 0.03 \\
$\mathrm{Ce}_{2} \mathrm{O}_{3}$ & 0.08 & 0.10 & 0.07 & 0.10 & 0.09 & 0.12 & 0.10 & 0.12 & 0.06 & 0.16 \\
$\mathrm{Pr}_{2} \mathrm{O}_{3}$ & 0.02 & 0.02 & 0.00 & 0.02 & 0.01 & 0.02 & 0.06 & 0.01 & 0.03 & 0.10 \\
$\mathrm{Nd}_{2} \mathrm{O}_{3}$ & 0.06 & 0.05 & 0.09 & 0.06 & 0.09 & 0.14 & 0.06 & 0.12 & 0.03 & 0.15 \\
$\mathrm{SrO}$ & 0.02 & 0.01 & 0.03 & 0.07 & 0.08 & 0.00 & 0.00 & 0.00 & 0.03 & 0.00 \\
$\mathrm{Total}$ & 101.01 & 101.49 & 101.65 & 100.47 & 100.87 & 99.15 & 99.36 & 100.71 & 101.40 & 99.03 \\
$\mathrm{O}=\mathrm{F}$ & 1.65 & 1.60 & 1.60 & 1.47 & 1.51 & 0.72 & 0.85 & 1.21 & 1.39 & 0.66 \\
$\mathrm{O}=\mathrm{Cl}$ & 0.02 & 0.02 & 0.02 & 0.02 & 0.02 & 0.17 & 0.09 & 0.05 & 0.01 & 0.11 \\
total & 99.34 & 99.87 & 100.03 & 98.99 & 99.34 & 98.26 & 98.42 & 99.45 & 100.00 & 98.25 \\
\hline
\end{tabular}

